\title{
Multitemporal Satellite Images for Knowledge of the Assyrian Capital Cities and for Monitoring Landscape Transformations in the Upper Course of Tigris River
}

\author{
Giuseppe Scardozzi \\ CNR-IBAM, Consiglio Nazionale delle Ricerche_-Istituto per i Beni Archeologici e Monumentali, Consiglio Nazionale delle Ricerche- \\ Istituto per i Beni Archeologici e Monumentali, Strada per Monteroni c/o Campus Universitario, 73100 Lecce, Italy \\ Correspondence should be addressed to Giuseppe Scardozzi, g.scardozzi@ibam.cnr.it \\ Received 4 February 2011; Accepted 23 March 2011 \\ Academic Editor: Nicola Masini \\ Copyright () 2011 Giuseppe Scardozzi. This is an open access article distributed under the Creative Commons Attribution License, \\ which permits unrestricted use, distribution, and reproduction in any medium, provided the original work is properly cited. \\ The paper is concerned with the contribution that a rich documentation of multitemporal optical satellite images with high re- \\ solution provides for the knowledge of the five great Assyrian capital cities (Ashur, Kar-Tukulti-Ninurta, Kalhu, Dur-Sharrukin, \\ and Nineveh, in northern Iraq). These images also allow monitoring changes of landscape in the higher course of the Tigris during \\ the last half century and document damages in archaeological sites during the two Gulf Wars. The data set, available for each \\ city, consists of panchromatic and multispectral images taken between 2001 and 2007 by modern commercial satellites (Ikonos-2, \\ QuickBird-2, and WorldView-1) and of panchromatic photographs of U.S. spy satellites operating between 1965 and 1969 (Corona \\ $\mathrm{KH}-4 \mathrm{~B}$ and Gambit KH-7). These photos were taken before diffusion of mechanized agriculture and the expansion of urban areas, \\ so they are very useful to document many archaeological features and the landscape that has been modified in the last decades, as \\ shown by recent satellite images.
}

\section{Introduction}

The work concerns the contribution that multitemporal high-resolution images, taken by optical satellites, provide for the study of archaeological sites in ancient Mesopotamia. Over the last decade, using VHR satellite data in archaeology became common, particularly in study areas where largescale maps or aerial photos are not available [1-3]. This paper regards the systematic use of these images for the knowledge of the five great Assyrian capital cities, sited in the modern northern Iraq. The data set, available for each city, consists of panchromatic and multispectral images taken between 2001 and 2007 by modern commercial satellites (Ikonos2, QuickBird-2, and WorldView-1) and of panchromatic photographs taken between 1965 and 1969 by United States reconnaissance satellites (Corona KH-4B and Gambit KH-7) before diffusion of mechanized agriculture and the expansion of urban areas. So, these multitemporal images also allow monitoring changes of landscape in the higher course of the Tigris during the last half century, and document damages in archaeological sites during the two Gulf Wars, especially the second.

1.1. The "Iraq Virtual Museum Project". The rich remotesensing data set used in this research was collected during the activities of the "Iraq Virtual Museum Project", conducted between 2006 and 2010 by the Italian National Research Council. The project was designed to create a rich website (http://www.virtualmuseumiraq.cnr.it/) based on the archaeological collection of the National Museum of Baghdad, which has been looted in 2003 during the 2nd Gulf War. The project realizes an innovative virtual museum of the civilizations of ancient Mesopotamia, from the emergence of the Neolithic villages (7000 BC) until the Islamic period (IX$\mathrm{X}$ century $\mathrm{AD}$ ); in the website, new digital communication systems allow to access into an impressive archaeological collection, currently not available yet [4]. The virtual tour is 
carried out across eight virtual exhibition "halls" organized according a chronological sequence.

In the "Iraq Virtual Museum Project", the Institute for Archaeological and Monumental Heritage has dealt with the contextualization of the objects shown in the virtual museum; they were ideally linked not only to the sites of provenance, but also to the cultural sphere to which they belong, thanks the use of multitemporal high-resolution satellite images and thanks to $3 \mathrm{D}$ virtual reconstructions, very useful for the documentation and communication of the archaeological areas. More specifically, ancient sources and data from previous studies and research were integrated with satellite remote-sensing documentation; 3D imagebased modelling techniques (photomodelling and digital photogrammetry) were used for the communication of the archaeological data [5]. In integration to the website, still in progress also is the realization of a webGIS that will allow a more detailed presentation of the archaeological sites, by means of multitemporal high-resolution satellite images, archaeological general maps and plans of the most important structures, and schedules of the historical and topographical development of the sites and their principal monuments; now, the sections concerning Dur-Sharrukin, Seleucia on the Tigris, and Hatra are completed [6].

The process of contextualization enables the museum "visitors" to view the original territorial contexts of finds, that is, the archaeological sites from which the materials came from. In the beginning stages, significant problems related to the documentation of the current state of these sites arose. Only a few terrestrial images and some oblique aerial photographs of limited sectors of the archaeological areas are generally available, together with some documents (graphic and photographic) of the excavations. An important contribution to solving this problem was provided by high-resolution multitemporal satellite images taken by recent commercial satellites during the 2000s. These images provided up-to-date and detailed documentation of the modern situation of the most important ancient cities and settlements of Mesopotamia; they are very useful in the presentation of archaeological sites (as a substitute for a real visit that is currently impossible) as well as for monitoring their transformation and preservation in recent years, particularly important in times of war. When it was possible, images of each archaeological site taken both before and after the Second Gulf War were used. For the documentation of the situation before the first Gulf War, numerous space photos of all the sites from the 1960s and 1970s, taken by United States reconnaissance satellites, and aerial photos from the 1920s, 1930s, and 1940s, taken by Royal Air Force pilots, were acquired and studied. The acquisition of these "historical" images was very important, as it allowed us to discover abundant data regarding territories that appear developed and have been partially modified and altered by the extension of urban areas or by realization of great infrastructures and the spread of mechanized agriculture devices.

So, the multitemporal remote-sensing data acquired during the project activities formed a fundamental documentation which made it possible to correctly "narrate" the main archaeological sites of Mesopotamia. They also made it possible to expand upon what is already known and discover new data regarding the ancient topography, urban layout and paleoenvironmental contexts, which are critical for the reconstruction of historical landscape in which the ancient settlements were located. In fact, high-resolution satellite images provided a detailed view from above of the current state of the archaeological sites and their layouts; they allow to see even the smallest of details and elements that are not easily perceptible on the ground (like ancient roads and canals now buried, paleoriver beds, etc.) and to recognize traces of ancient structures that are still buried or that have been interred since their original excavation.

\subsection{The Case Study Concerning the Assyrian Capital Cities.} The case of the Assyrian capital cities (Ashur, Kar-TukultiNinurta, Kalhu, Dur-Sharrukin, and Nineveh), in northern Iraq (Figure 1), is exemplificative about the importance of the integrated use of "historical" space photos and recent satellite images. Ashur (modern Qal'al Sherqat) is located $390 \mathrm{~km}$ north of Baghdad, on the western bank of the Tigris River, about $27 \mathrm{~km}$ north-west of the confluence with its tributary Little Zab River. The city was occupied continuously starting from the early Dynastic period and was the main administrative capital of the Assyrian Empire during most of the Old and Middle Assyrian periods. Ashur was supplanted for some time during the Middle Assyrian period by Kar-Tukulti-Ninurta (modern Tulul al-'Aqr), the new capital city founded by king Tukulti-Ninurta I (1233$1197 \mathrm{BC}$ ); it is located about $4 \mathrm{~km}$ to the north of Ashur, on the east bank of the Tigris. The capital subsequently reverted to Ashur until king Ashurnasirpal II (883-859 BC) expanded the older city of Kalhu (modern Nimrud), located $70 \mathrm{~km}$ north, on the east bank of the Tigris valley, $11 \mathrm{~km}$ north of the confluence with its tributary Greater Zab River. Kalhu remained the royal capital during much of the 9th and 8th centuries BC, followed by Dur-Sharrukin (modern Khorsabad), the new city built by king Sargon II (721-705 BC) between the years 713 and 707 BC in the plan northeast of modern Mosul, about $13 \mathrm{~km}$ away. The final Assyrian capital was Nineveh, already an ancient and important royal city when Sennacherib (704-681 BC) designated it the imperial capital. The area of the ancient city, enlarged by Sannacherib, on the eastern bank of the Tigris, $28 \mathrm{~km}$ northwest of Kalhu, is today surrounded and partially overlaid by new suburbs of Mosul. Nineveh remained the capital of the Assyrian Empire until its destruction in 612 BC by the Medes, Babylonians, Scythians, and Elamites.

During the last decade, a systematic study of landscape and settlement in the Neo-Assyrian Empire was conducted using old aerial photos, Corona KH-4B and Gambit $\mathrm{KH}-7$ photos, and low-resolution $(15 \mathrm{~m})$ modern ASTER (advanced spaceborne thermal emission and reflection radiometer) images [7-15]. The present research (of which this paper is a preliminary report) integrates the results of the previous studies, with the important contribution of the integrated use of recent high-resolution satellite images in the knowledge and monitoring archaeological evidence of the Assyrian capital cities and ancient roads and canals of the surrounding territories. Particularly, the knowledge of 


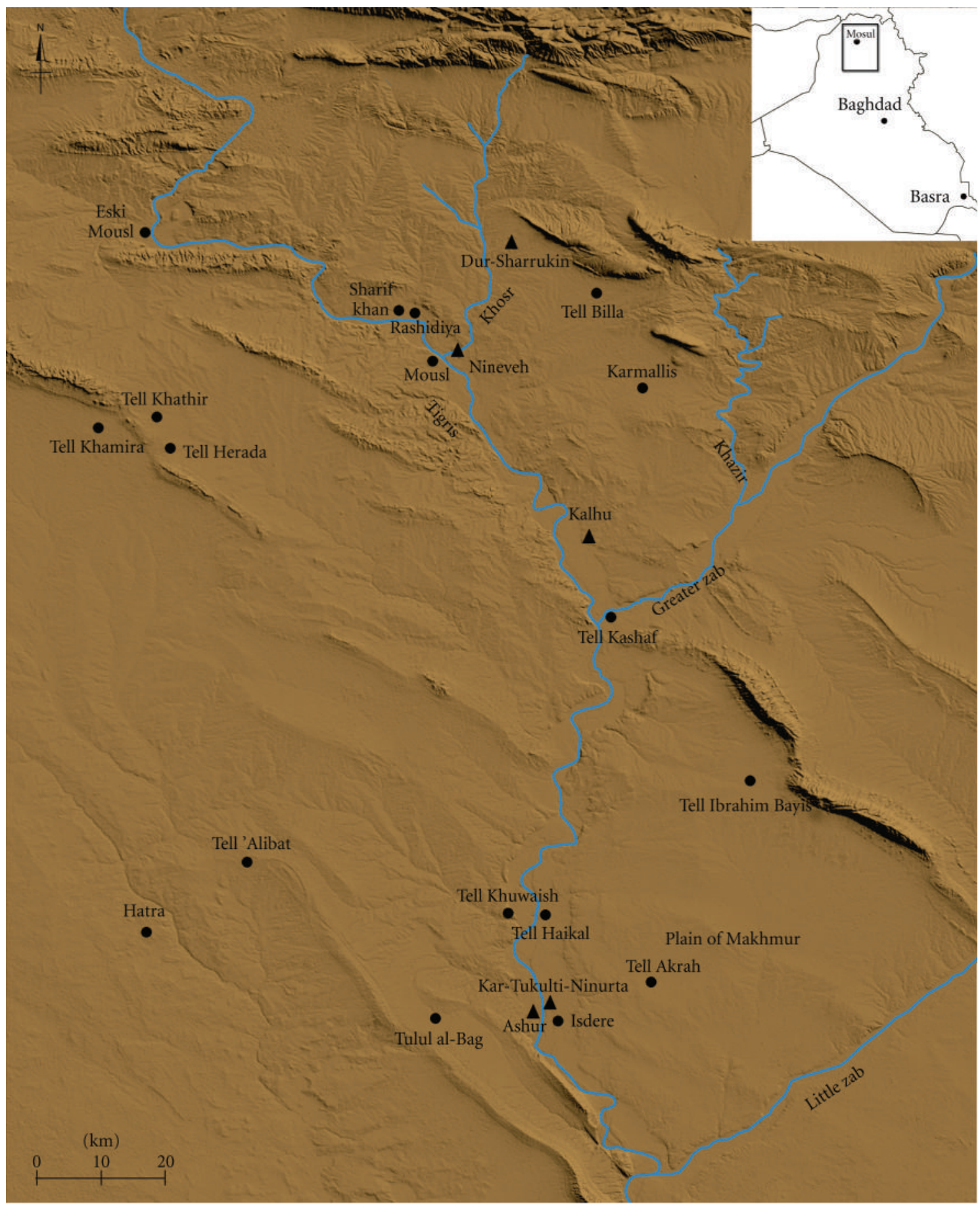

FIGURE 1: DEM (based on the shuttle radar topography mission) of the northern Iraq: the study area and the Assyrian capital cities along the Tigris valley are shown.

the ancient evidence scarcely visible on the surface and the monitoring of the archaeological remains are urgent needs in a landscape like the upper Tigris valley and the surrounding territories that during last decades are strongly changed. As example, it is important to highlight that in a report of October 2010 titled "Saving Our Vanishing Heritage", Global Heritage Fund named Nineveh one of the 12 sites most "On the Verge" of irreparable loss and destruction, citing insufficient management, development pressures, and looting as primary causes.

\section{Data Set and Methodology}

In Iraq, remote sensing was a very important part of archaeology for a century, from the aerial photographs taken during the First World War by Royal Air Force pilots [16, 17]. 
However, today, easy access to aerial photography is often impossible to obtain. As a result, archaeologists have turned to optical satellite images, both declassified Corona and Gambit photos of the years 1960s and 1970s, and recent commercial high-resolution images (panchromatic and multispectral) that unfortunately are more expensive.

Corona was a United States Department of Defense intelligence program, operative from 1959 to 1972, which encompassed several "Keyhole" camera systems (KH-1 through KH-6). Corona photographs (about 860,000) were declassified by executive order in 1995 and have been publicly available since 1998; they can be acquired by the United States Geological Survey (http://edc.usgs.gov/). Archaeologists operating in the Near and Middle East were quick to recognize the potential of this new dataset, and these images were used during researches in several countries, such as Turkey, Syria, and Iraq $[14,18]$. In the present study, only photos taken by Corona KH-4B satellites (operative from September 1967 to May 1972) are employed; they have the best ground resolution of the program (about $1.83 \mathrm{~m}$ ), were taken in stereo utilizing forward and aft panoramic cameras, and covered all the study areas.

Gambit KH-7 Surveillance System was another reconnaissance satellite used by United States from July 1963 to June 1967, which produced high-resolution imagery that improved from 1.2 to $0.6 \mathrm{~m}$ over the course of the program. Its photos (about 19,000) were declassified in August 2002 and are available in USGS. The Gambit $\mathrm{KH}-7$ coverage was much more limited than Corona satellites; most of its photos regarding Soviet and Chinese nuclear and missile installations, with smaller amounts of images concerning cities and harbors: Mosul was one of the urban centres targeted. As a result, several photographs of Nineveh and of the surrounding area from five KH-7 missions of the years 19651967 are available, and one of them covers also the area of Dur-Sharrukin; all these photos were used during the present study.

Corona and Gambit photos were used for direct visual analysis without any geometric preprocessing. The ground resolution of the photos acquired during the later Gambit KH-7 missions (in 1966 and 1967) can be compared favorably with the best commercial systems, such as Ikonos-2, Quickbird-2, and WorldView-1. Several images of the last satellites were acquired from the companies owning the platforms (http://www.geoeye.com/; http:// www.digitalglobe.com/), and others are analyzed in Google Earth; these images, taken between 2001 and 2007, have a very high-resolution (between 0.50 and $1 \mathrm{~m}$ in panchromatic mode, and between 2.40 and $4 \mathrm{~m}$ in multispectral mode), and allow to investigate the visible and the near infrared; they don't have the typical geometrical distortion of Corona and Gambit photos, but are bought pre-processed (Ikonos Geo Ortho Kit level; QuickBird and WorldView Standard Ortho-ready levels) and with a radiometric resolution of 11 bits per pixel. Because of their high cost, only commercial images of the urban area (and its neighbors) of the Assyrian capital cities were purchased. These current high-resolution images were orthorectified by using a DEM based on SRTM data and the Rational Polynomial resampling model; DEMs were also draped with spatial photos and satellite images for a 3D analysis of remote sensed documentation. In some cases (Dur-Sharrukin and Nineveh), even an automatic co-registration of recent satellite images was performed, and it was very useful for multitemporal analysis of pre- and post-Second Gulf War situations.

The data set concerning the Assyrian capital cities and their surrounding territory is the following:

(i) Ashur and Kar-Tukulti-Ninurta: five Corona KH-4B photos (December 11, 1967; August 16, 1968; December 6, 1969; resp., missions 1102, 1104 and 1108); two QuickBird-2 images (September 10, 2002; August 2, 2005),

(ii) Kalhu: two Corona KH-4B photos (August 16, 1968, and December 6, 1969, resp., missions 1104 and 1108); one QuickBird-2 image (August 10, 2002); one Ikonos-2 image (September 15, 2007),

(iii) Dur-Sharrukin: one Gambit KH-7 photo (April 30, 1965, mission 4017); two Corona KH-4B photos (August 16, 1968, and December 6, 1969, resp., missions 1104 and 1108); one Ikonos-2 image (February 2, 2001); four QuickBird-2 images (June 4, 2002; June 30, 2003; August 20, 2004; August 2, 2005),

(iv) Nineveh: six Gambit KH-7 photos (April 30, 1965; May 16, June 5 and September 20, 1966; June 8 and 9, 1967; resp., missions 4017, 4028, 4029, 4031 and 4038); two Corona KH-4B photos (August 16, 1968, and December 6, 1969, resp., missions 1104 and 1108); nine QuickBird-2 images (June 4, July 4 and October 2, 2002; June 25 and August 30, 2003; April 8, August 20 and December 29, 2004; February 16, 2005); one WorldView-1 image (December 22, 2007).

During the activities of the "Iraq Virtual Museum Project," the study and the analysis of this multitemporal documentation represented an opportunity to acquire new data about the ancient topography of the archaeological sites examined. It is very important specifically for contexts that have been studied many years ago or that are characterized by a history of the research focus mainly on individual complexes, monuments, or wealth of finds and less interested in the general layout of settlements. The use and the analysis of the Corona $\mathrm{KH}-4 \mathrm{~B}$ and Gambit $\mathrm{KH}-7$ photos (and of the recent panchromatic satellite images) is the same of the traditional aerial photos, in which archaeological features are highlighted by microrelief and shadow and soil and crop marks [19]. These images predate the introduction of the large-scale irrigation schemes and industrial-scale agriculture schemes that have been so destructive to the cultural heritage of northern Iraq; moreover, they document Mosul and the villages along the Tigris course before the booming of their urban areas in the last decades, which have covered and destroyed a lot of archaeological features. In some cases, Corona and Gambit photos constitute a precious documentation of archaeological areas before any recent transformations and in some cases have shown ancient features that nowadays are not visible or have been destroyed. 


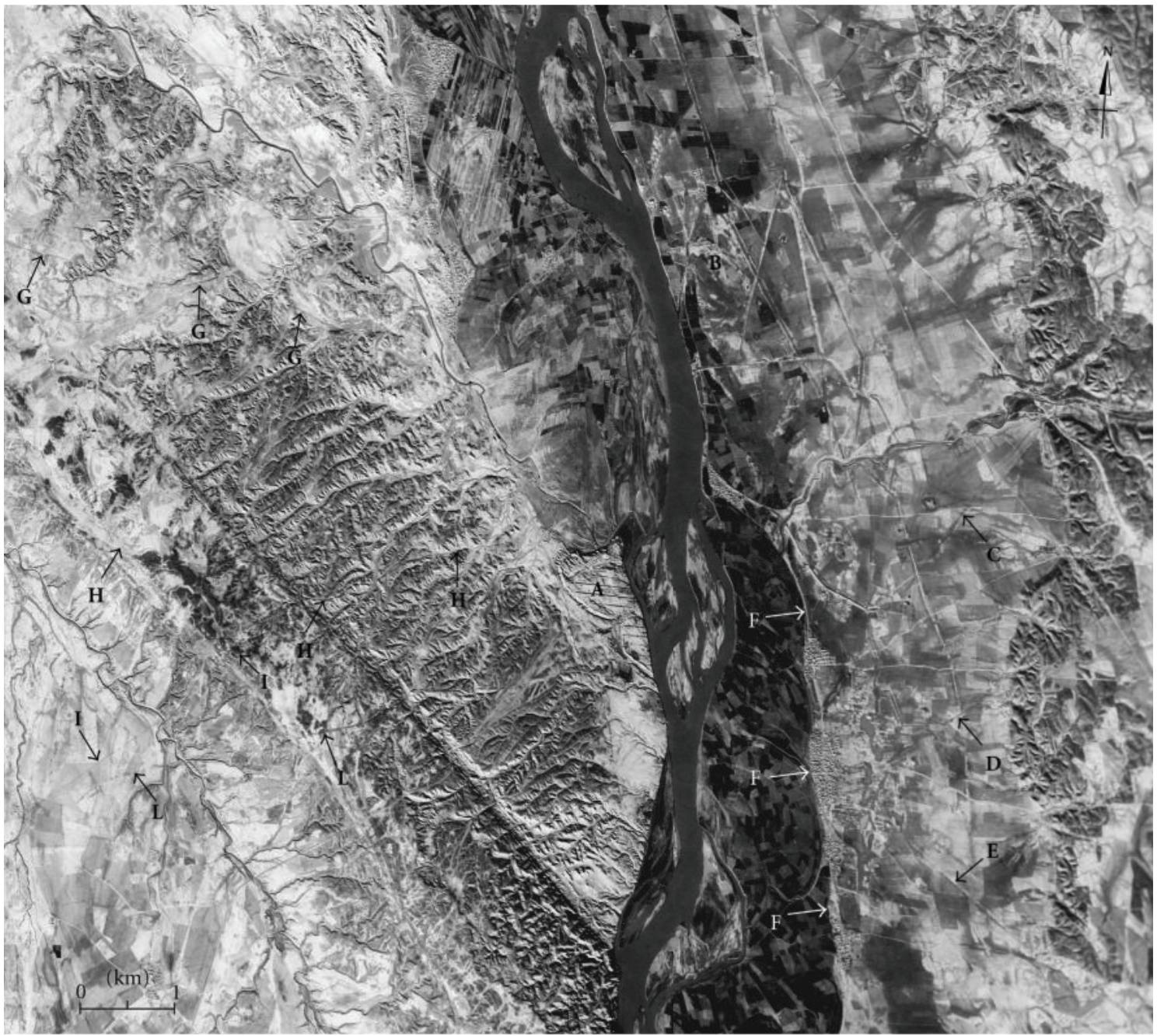

Figure 2: The area of Ashur (A) and Kar-Tukulti-Ninurta (B) in a Corona KH-4B image of 1967; traces and remains of ancient roads (C, D, E, $\mathrm{G}, \mathrm{H}$, and I) and a relict river meander of the Tigris (F) are also visible.

So, they are particularly useful for the reconstruction of ancient landscapes or aspects of the territories which are more similar to the ancient ones.

The Corona and Gambit space photos are the primary remote-sensing sources for locating archaeological and even paleoenvironmental features in the study areas; they show a lot of ancient remains and traces and anomalies linked to buried archaeological features, in particular sites, structures, walls, canals and roads, that is, the so-called "hollow ways" [15]. These linear hollows are remnants of ancient roads that can be commonly found in the Jazirah region (northern Iraq and Syria), caused by the continuous use of tracks by men and animals, and also by vehicles such as sleds, carts, or wagons $[20,21]$; these features can be described as shallow linear depressions that have different soil, moisture and vegetation characteristics from the surrounding terrain. Since hollows have an elevation that is generally lower than the surrounding area, water is often captured at the bottom of the features; this enables more vigorous plant growth in the troughs. In the panchromatic images, these features are distinguishable from the soil by darker color than the sur- rounding area. Even canals and remnants of canals have depressions that have similar properties to hollow ways, with moisture collecting and vigorous vegetation growing in the shadows, so cases of ambiguity between canals and linear hollows are present. In contrast to linear hollows, remnants of canals often have spoil banks that are composed of materials cast up from their excavation as well as silts cleaned out from the channels.

Recent commercial satellite images were used to document in detail the modern developed landscape in the ancient sites. They allowed monitoring of the archaeological areas and generally documented the destruction of a lot of ancient features; in certain areas, these images confirmed the existence of archaeological features and also showed them more clearly than the Corona and Gambit photos. Moreover, the Ikonos-2 and QuickBird-2 systems both integrate very high geometric resolution with multispectral characteristics that have a lot potentialities in the archaeological research; for example, the near infrared band was very useful in highlighting buried features that produce a different vegetation growth on the surface. So, in some cases, the processing of 


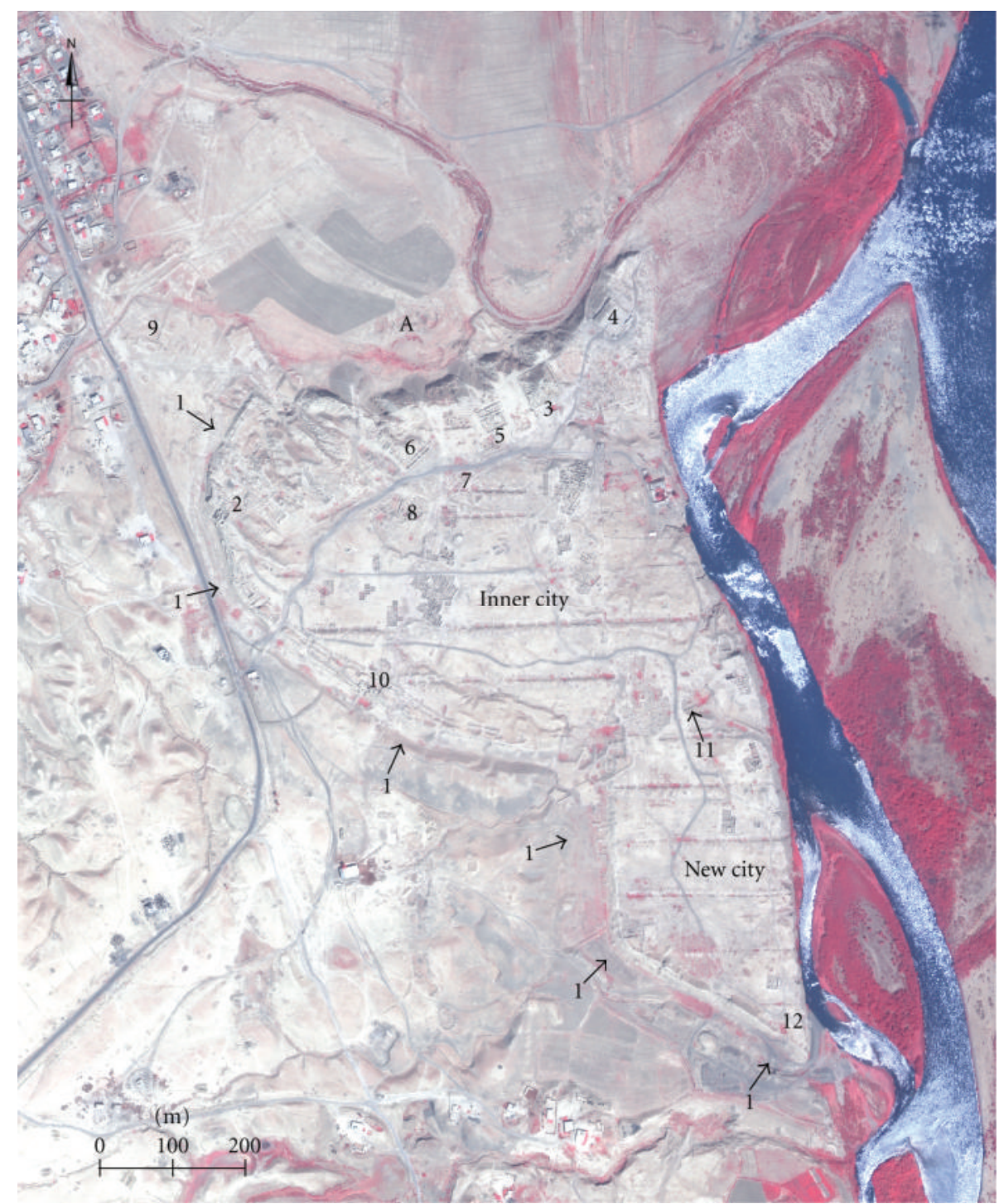

FIGURE 3: Ashur in a pan-sharpened (bands 4-3-2) QuikBird-2 image taken in 2005: (A) ancient river course of the Tigris; (1) moat outside the city walls; (2) Tabira Gate; (3) Ziggurat; (4) Temple of Ashur; (5) Old Palace and Palace of Adad-nirari I; (6) Temple of Anu and Adad; (7) Temple of Sin and Shamash; (8) Temples of Ishtar and of Nabu; (9) Akitu Temple; (10) West Gate; (11) South Gate of the inner walls; (12) South Gate of the outer walls.

multispectral images of Ikonos-2 and QuickBird-2, in which the measured radiation is divided in four bands including the visible spectrum and the near infrared, and the data fusion between panchromatic images and multispectral elaborations also made it possible to identify and highlight, in a better way, archaeological and paleoenvironmental traces and anomalies.

However, in the analysis of remote-sensing data, the verification on the ground of presences, traces and anomalies is very important, in order to clarify their real pertinence to archaeological elements, their interpretation, and, if possible, also their dating, avoiding misunderstandings, and mistakes; in fact, field work verification is the only way to fully certify any observation in the images. But in the study cases of the Assyrian capital cities (and also of the other archeological sites considered in the "Iraq Virtual Museum Project"), the ground control with a survey of the sites was impossible, so often, we can formulate only hypotheses, and other verification methods of features observed must be used to certify the results as best as possible: for instance, by observing characteristics from known features, or using multiple images of the same areas, with the aim to verify that features visible on one image can be found in another image from a different time. So, all sites in this study were examined through analysis of multiple images taken in different years and seasons, because features identification is heavily dependent on ground conditions at the time of acquisition. By overlaying the different satellite images, it has been possible to extract information from them to arrive at a composite reconstruction that is in part visible in all of them but rarely completely visible in any single image. 


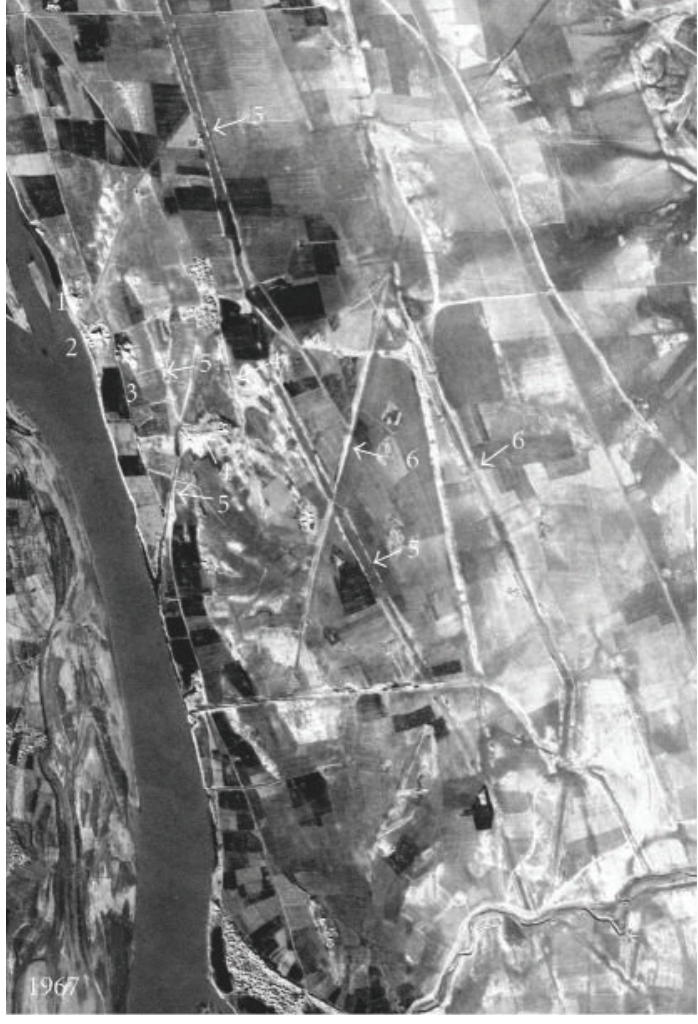

(a)

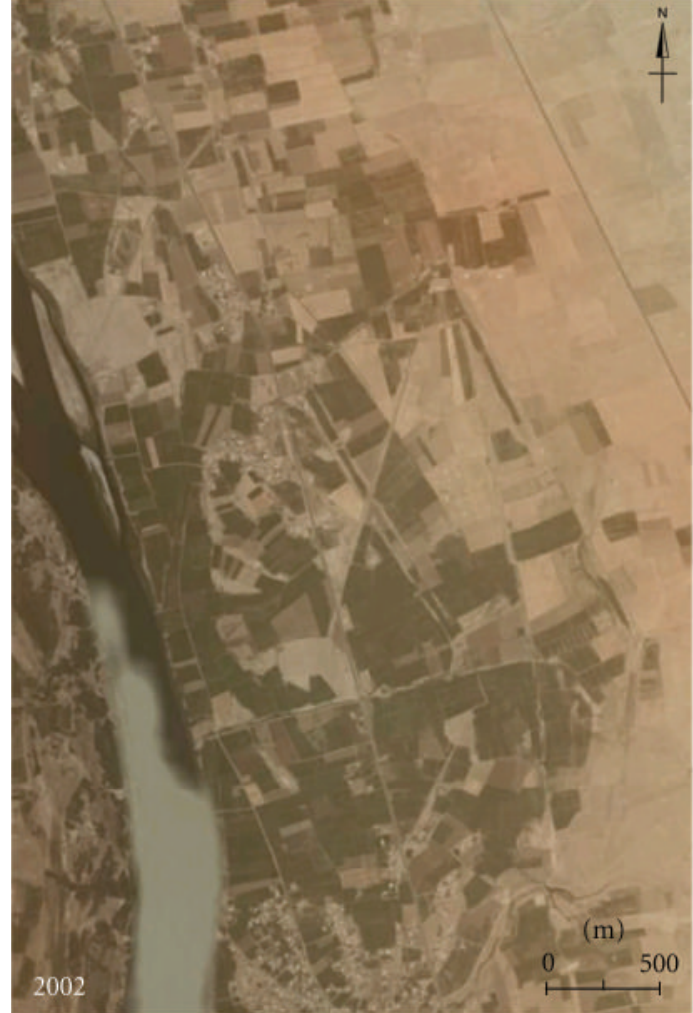

(b)

Figure 4: (a) Corona KH-4B image of 1967 and (b) pan-sharpened (bands 3-2-1) QuickBird-2 image of 2002 showing the area of KarTukulti-Ninurta. In the old space photo, the remains of the ancient capital city are well visible: (1) north Palace; (2) Ashur Temple and Ziggurat; (3) south Palace; (4) city walls; (5) Assyrian canals; (6) Islamic canals.

\section{Some Results}

About each Assyrian capital city, some of the principal results of the research are preliminary presented as examples. A more detailed atlas concerning the contribution of multitemporal remote-sensing data for the study and reconstruction of the ancient sites of Mesopotamia is in progress. It will be a hardcopy volume where all the documentation elaborated for the project and related to the archaeological sites will be collected: that is, processed satellite images and space photos, new archaeological plans and maps derived from the processing and analysis of remote-sensing data [22], virtual reconstructions, and reports concerning the historical and topographical development numerous ancient Iraqi sites from the Prehistory to the Islamic period (in addition to the Assyrian capital cities, also Ur, Uruk, Tell Es-Sawwan, Tell Asmar, Babylon, Sippar, Kish, Seleucia on the Tigris, Ctesiphon, Hatra, Samarra, and Ukhaydir).

3.1. Ashur and Kar-Tukulti-Ninurta. Ashur and Kar-TukultiNinurta, respectively, on the west and the east banks of the Tigris, are well documented by a Corona $\mathrm{KH}-4 \mathrm{~B}$ photo taken in 1967 (Figure 2 (A-B)). Traces of the ancient roads that connected Ashur to the important Middle Assyrian and NeoAssyrian towns of Tell Akrah and Tell Ibrahim Bayis (Figure 2 $(\mathrm{C}-\mathrm{D}))$, located, respectively, east and north-east of the city, in the plain of Makhmur (called in antiquity mat Ashur, i.e., "land of Ashur") are visible [7, 8, 11, 13, 15]; also traces of roads leading toward south-east are clear in the space photo (Figure $2(\mathrm{E})$ ). Many of these hollow ways east of the Tigris seem to converge south-east of Ashur, near the modern village of Isdere and a relict river meander visible in the satellite image (Figure $2(\mathrm{~F})$ ), in the eastern bank of the alluvial valley; it is possible that travellers to and from Ashur crossed the river at this juncture on a ferry or bridge. To the west of the city, other hollow ways are visible in the Corona space photo (Figure $2(\mathrm{G}-\mathrm{L})$ ); they can be tied to specific gates mentioned by historical texts and revealed in excavations, such as Tabira Gates in the north-western sector of the city walls. In particular, these ancient roads connected Ashur to sites such as Tulul al-Bag and Tell 'Alibat (resp., sited west and north-west of the city) occupied in Neo-Assyrian period and perhaps also in the Middle Assyrian period. It is, therefore, significant that at least one hollow way, leading toward north-west (Figure $2(\mathrm{G})$ ), connected Ashur to Hatra in the Parthian period, when the first city continued to have an important role.

The Corona KH-4B photo of 1967 contextualizes Ashur along the west bank of the Tigris; they also document the high escarpment and the trace of the arm of the river on the northern side of the city and the moat that was excavated outside the fortification system in the southern and western 


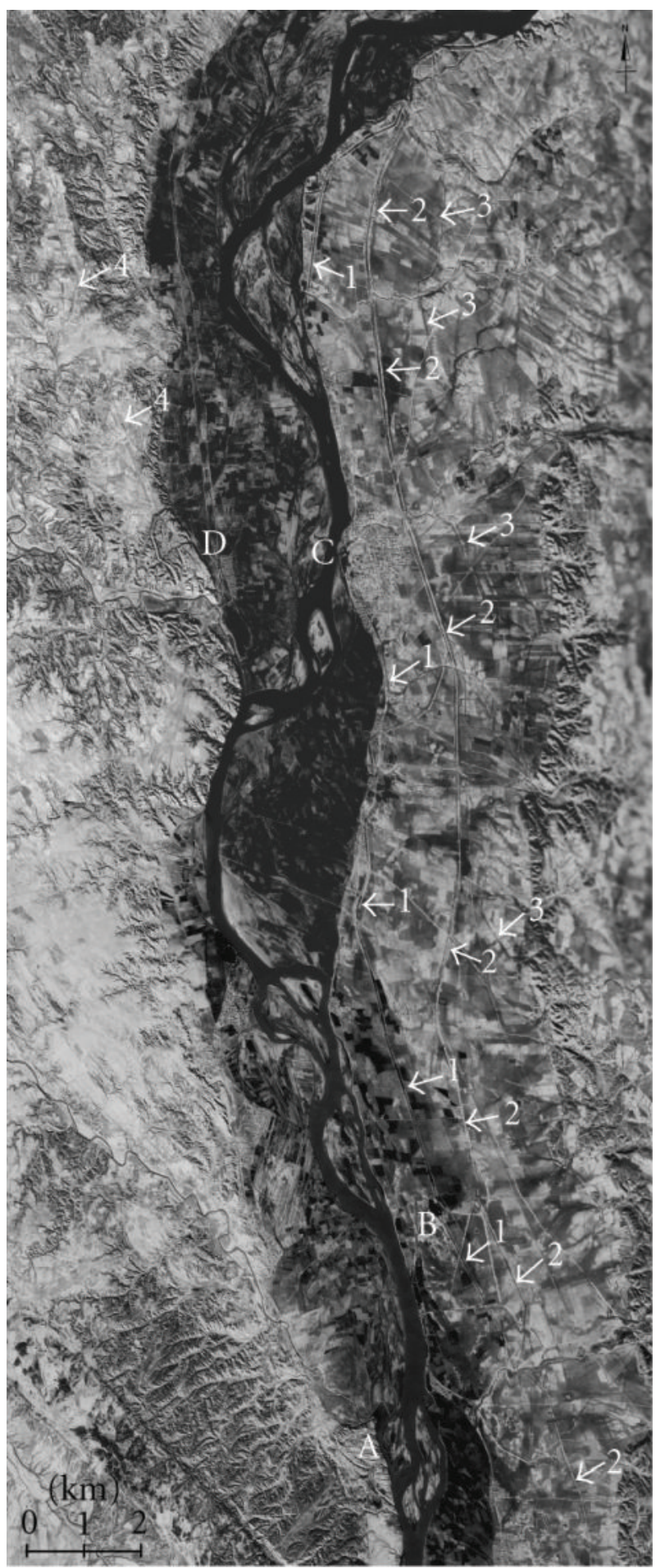

Figure 5: Assyrian and Islamic canals in the Tigris valley north of Ashur (mosaic of Corona KH-4B photos of 1967): (1) Pattu-mēšari; (2) Nahr Qanausa; (3) off-takes or secondary branches of the Nahr Qanausa; (4) hollow way; (A) Ashur; (B) Kar-Tukulti-Ninurta; (C) Tell Haikal; (D) Tell Khuwaish.

sides. A QuickBird-2 image of 2005 (Figure 3) allows a more detailed view of Ashur, with the city walls (about $4 \mathrm{~km}$ long) that surround the urban area (about 65 ha), the "Inner City" and the "New City" on the south, separated by a wall, and the excavated buildings. A detail of the Corona photo of
1967 shows the remains of Kar-Tukulti-Ninurta excavated in 1913-1914, better preserved than today (Figure 4). The city was enormous (about 500 ha) and characterized by a walled area of about $800 \times 800$ meters that enclosed the royaladministrative quarter, divided into two halves by a canal 


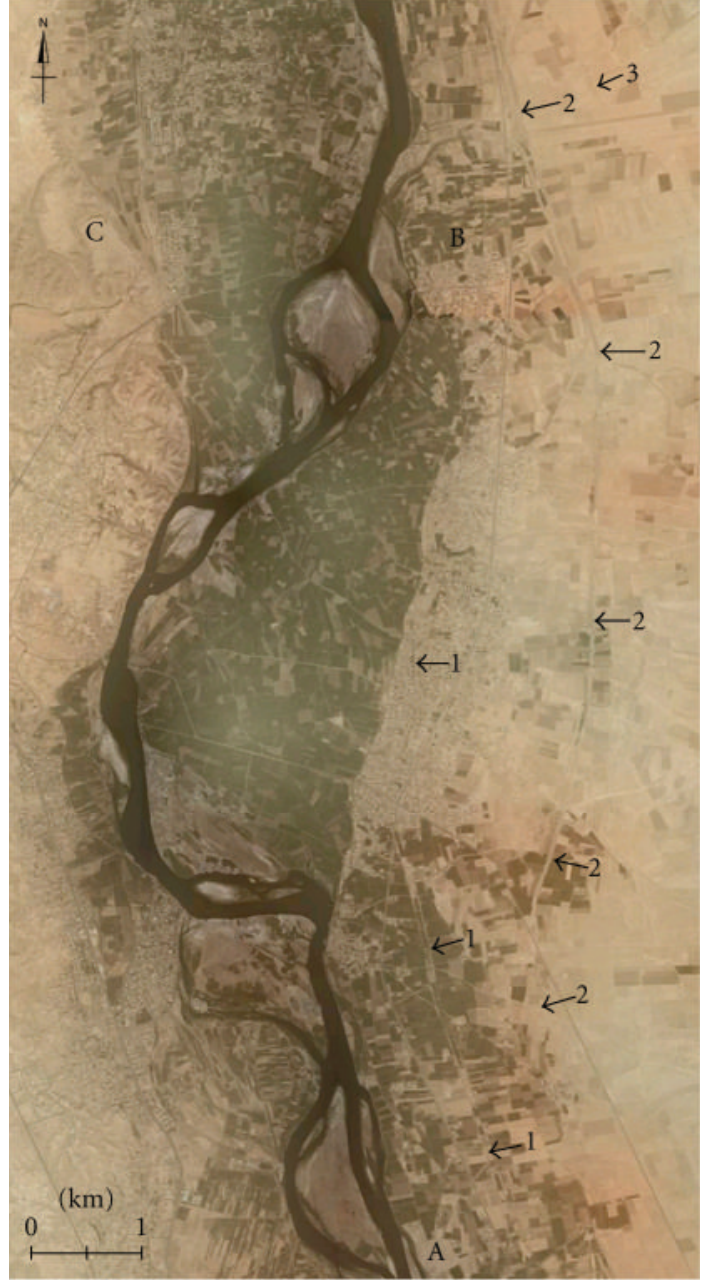

Figure 6: Remains of Assyrian and Islamic canals along the eastern bank of the Tigris, between Kar-Tukulti-Ninurta (A) and Tell Haikal (B), in a pan-sharpened (bands 3-2-1) QuickBird-2 image of 2002: 1, Pattu-mēšari; 2, Nahr Qanausa; 3, off-takes or secondary branches of the Nahr Qanausa. On the west bank of the river is Tell Khuwaish (C).

running roughly north-south almost the entire length of the city with a monumental gate at its southern end; this canal (Figure 4 (5)) was identified with a branch of the Pattumešsari ("Canal of Justice"), mentioned by historical texts and built by the same king Tukulti-Ninurta I (1233-1197 BC), who founded the city. The area of Kar-Tukulti-Ninurta is also crossed by branches or off-takes of an Islamic canal (Figure 4 (6)), the Nahr Qanausa, used about from the 7th to 16 th century AD.

The area north of Ashur, along the eastern bank of the river, where is located Kar-Tukulti-Ninurta, as described, is, in fact, characterized by the presence of some ancient canals (dated in the Assyrian and the Islamic ages) [15], which are well visible in the satellite images and crossed an area partially transformed in recent years by agricultural works, expansion of villages, and building of infrastructures (Figures 5 and 6). The main remains of these canals, which have provided water to the alluvial plain along the east bank of the Tigris, are associated with the Pattu-mēšari and the

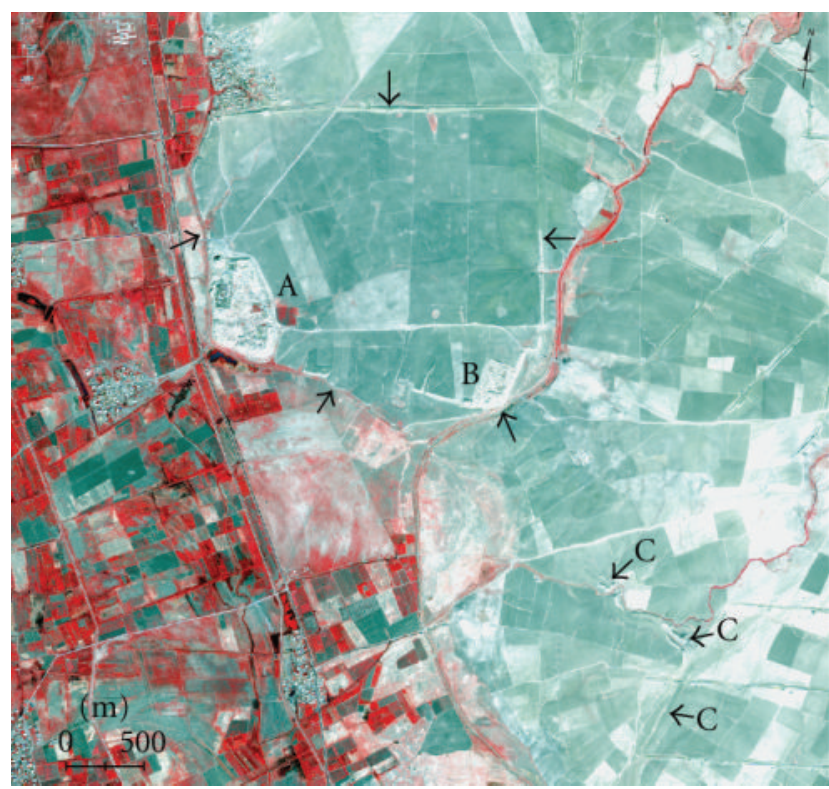

Figure 7: Kalhu in a pan-sharpened (bands 4-3-2) Ikonos-2 image of 2007: (A) Tell Nimrud; (B) Fort Shalmaneser; (C) traces and remains of the Assyrian canal identified with the Patti-nuši; big arrows show traces and remains of the city walls.

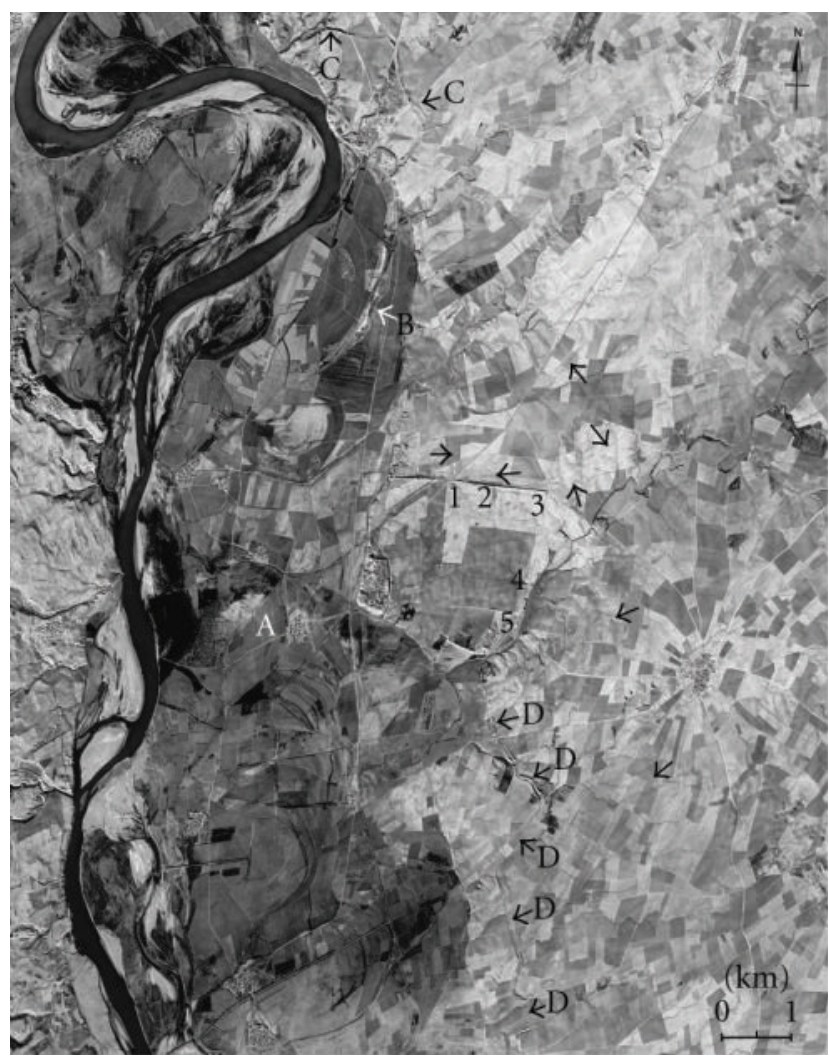

FIgURE 8: Kalhu and the surrounding territory in a Corona $\mathrm{KH}-4 \mathrm{~B}$ photo of 1969: (A) Tigris valley and traces of paleo-river beds; big arrows show traces of ancient roads, while small arrows point traces and remains of ancient canals $(\mathrm{B}, \mathrm{C}$, and $\mathrm{D}) ; 1-5$, gates along the city walls. 


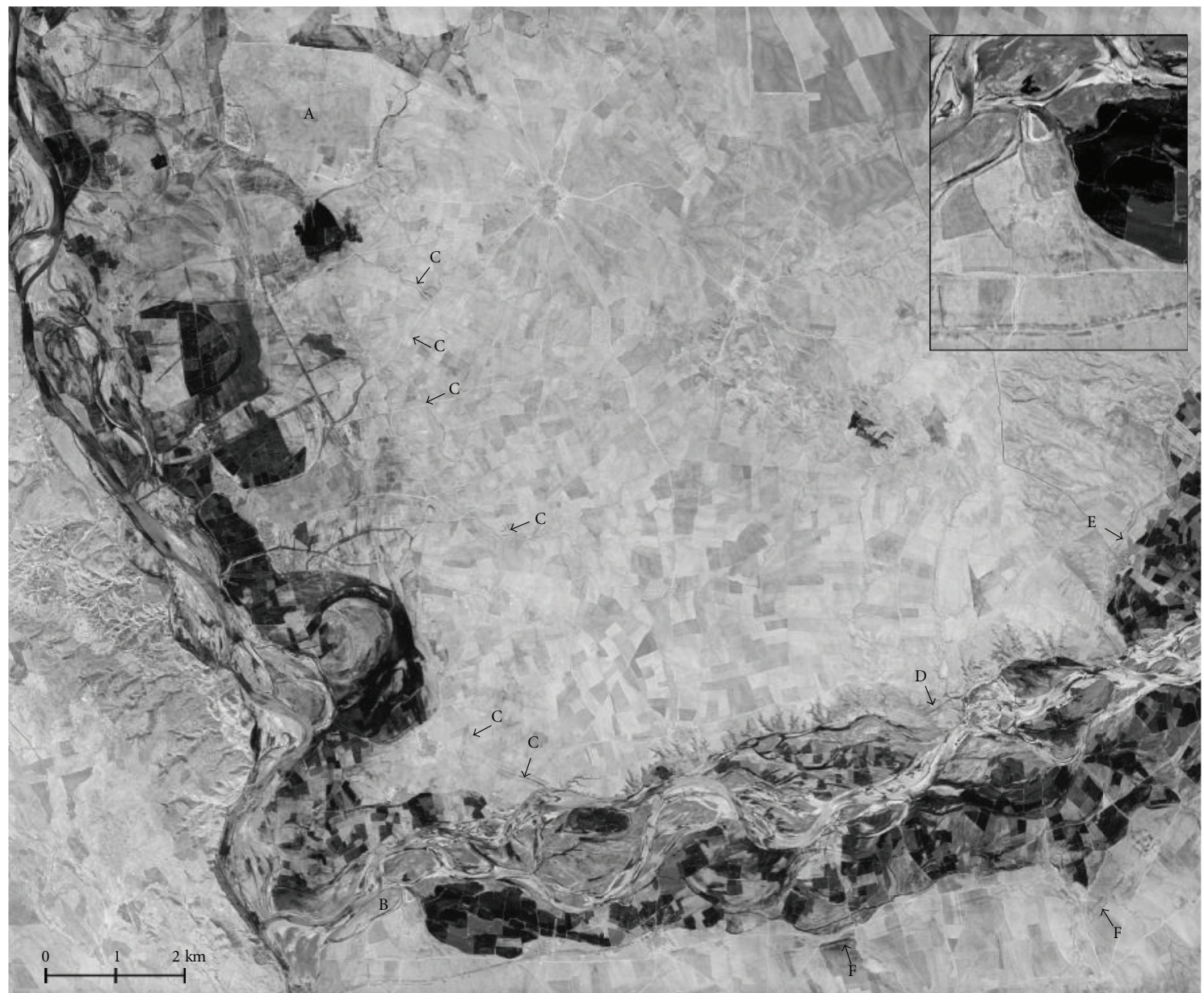

Figure 9: The territory of Kalhu (A) in a Corona KH-4B photo of 1968; Tell Kashaf (B) and traces and remains of the Assyrian canal named Patti-nuši (C, D, and E) and of another canal dated post the Neo-Assyrian period can be seen (F); an enlargement of the image shows the Assyrian settlement of Tell Kashaf, strategically located very near to the juncture of the Upper Zab and the Tigris.

Nahr Qanausa. Both canals tapped the Tigris in a location that is about $25 \mathrm{~km}$ north of Ashur and lied roughly northsouth parallel the river; they have clear spoil heaps and are both relatively wide and long. The Pattu-mēšari defined the eastern boundary of Kar-Tukulti-Ninurta and extended well north of the city, crossing also the area of Tell Haikal (may be the ancient Ekallate), a site located $15 \mathrm{~km}$ north of Ashur and next to the Tigris on the east bank; it was occupied in the Middle Assyrian, Neo-Assyrian and post-Assyrian periods. On the other bank of the river, at the same distance from Ashur, is Tell Khuwaish (may be the ancient Ubase), also well documented by the satellite images (Figures 5 (D) and $6(\mathrm{C})$ ); it has a large defensive wall and was occupied in the Neo-Assyrian and post-Assyrian periods. An ancient road from this site toward north-west is also visible (Figure 5 (4)). The Pattu-mēšari, built in the Middle Assyrian period, may have continued to be used in the Neo-Assyrian period and irrigated the region near Ashur. The Nahr Qanausa is well visible in the satellite images and illustrates large-scale irrigation activity in this area during the Islamic period; the canal measured up to $100 \mathrm{~m}$ or more in width between its two banks and was $35 \mathrm{~km}$ long. Possible off-takes or secondary branches of this canal are also visible.
3.2. Kalhu. Satellite images clearly show the perimeter of the city walls (about $8 \mathrm{~km}$ long), which delimits the large urban area of Kalhu (roughly 380 hectares), and the two main areas of excavation, Tell Nimrud, in the south-western corner of the city, and Fort Shalmaneser in the south-eastern corner (Figure 7 (A-B)) $[18,23]$. The city walls of Kalhu were built by king Ashurnasirpal II (883-859 BC), who considerably expanded the small Middle Assyrian settlement. The northern and eastern sides of the city walls are straight, while the other two were more irregular in shape, following the morphology of the territory; specifically, they followed the top of a short slope, leading down to the Shor Derreh stream, which flows along the south-east corner of the urban area and an ancient arm of the Tigris. In fact, Kalhu stood near the eastern bank of the Tigris, which ran along the western and south-western limit of the urban area and which today flows roughly $3 \mathrm{~km}$ further west.

A Corona KH-4B photo of 1969 is useful for documenting the ancient landscape around the city. Kalhu appears along the eastern bank of the Tigris valley, highlighted by residual humidity in the ground (Figure 8 (A)); in the valley, the traces of several paleo-river beds of the Tigris along 
the western and south-western boundaries of the city are clearly visible. In the Corona photo, the perimeter of the city walls is more evident than today and less damaged by agricultural works (in particular, on the eastern side). In the same image, traces of ancient roads and canals are also well visible [15]. Ancient routes, shown in the space photo as grey linear features, can be seen to the south-east, east, and northeast of Kalhu; they probably started from the gates along the city walls, on the northern and eastern sides of the urban area (Figure $8(1-5)$ ). To the north-west of Kalhu, several canal excavations with developed spoil banks can be seen (Figure $8(\mathrm{~B}-\mathrm{C})$ ) although it is unclear when these features would have been created. The northernmost canal on the image appears to have been cut into the bedrock or at a depth that would have created relatively large spoil banks. These canals could have been used during high water levels to divert overflow from the Tigris into the terraces above the alluvial areas surrounding the river, so these canal may have been intended to transport water to the south-east [15]. South of the city, the evident remains of another ancient canal are visible (Figure 8 (D)); it reached the south-eastern corner of the urban area coming from the Greater (or Upper) Zab River. This canal, today less preserved due to agricultural activities (Figure $7(\mathrm{C})$ ), is identified with the Patti-nuši ("Canal of Abundance") mentioned by historical texts and its remnants are well documented by a Corona $\mathrm{KH}-4 \mathrm{~B}$ photo taken in 1968. In this image, the route of the canal until the Great Zab, $9 \mathrm{~km}$ away and where is the Negub tunnel, can be seen (Figure $9(\mathrm{C})$ ); here, along the southern bank of the river is Tell Kashaf, a large site which is dated to both the Middle Assyrian and Neo-Assyrian periods, and is associated to the ancient city of Kasappa, mentioned in the written sources.

Other remains of the Patti-nuši are visible south-east and east of the city (Figure 9 (D-E)), where the canal flowed parallel to the river. In fact, the Patti-nuši originates from the Khazir River (a tributary of the Great Zab which flowed north-east of Kalhu), then turning south toward the Zab and appears to have flowed parallel with this river until it reached directly south of Kalhu. From there, the channel runs north, with the canal likely having emptied its water into the area immediately around the city, where it irrigates meadows and gardens; it also provided the irrigation of the land just east its route, in the Tigris valley. The historical texts suggest at least two major construction phases for the canal and its conduit [15]. The initial canal built by Ashurnasirpal II may have been relatively small, leading from the Negub tunnel to Kalhu. It is possible that the segment of the Patti-nuši parallel to the Greater Zab and the course connecting to the Khazir River might have been a second phase constructed during Esarhaddon's reign (681-669 BC).

Immediately to the south of the Greater Zab and parallel to this river, and lying near Tell Kashaf, remnants of another canal with clear spoil bank can be seen in the Corona $\mathrm{KH}$ 4B photo of 1968 (Figure 9 (F)). The date of this feature is unclear given the lack of field work; considering its characteristics, the canal is dated post the Neo-Assyrian period. Lastly, a QuickBird-2 image of 2002 (visible in Google Earth: consultation of March 2011) shows the modern situation of

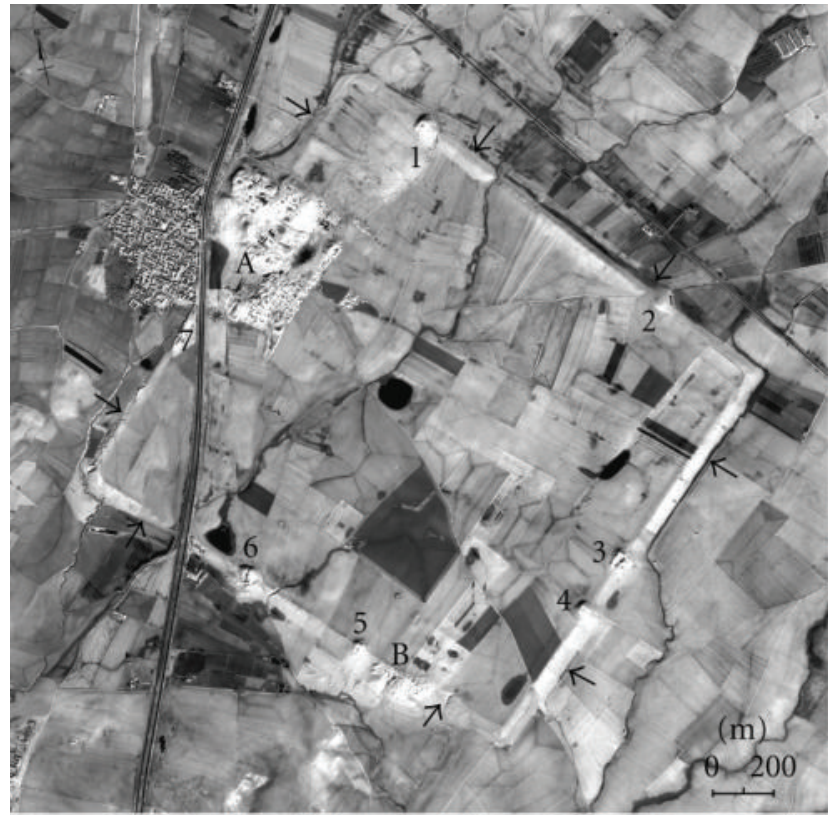

FIGURE 10: Dur-Sharrukin in an Ikonos-2 panchromatic image of 2001: (A) Palace of Sargon II; (B) Palace F; 1-7, gates along the city walls.

the territory of Kalhu, where agricultural activities of last decades have damaged some ancient features.

3.3. Dur-Sharrukin. An Ikonos-2 image of 2001 (Figure 10) shows the quadrangular plan of Dur-Sharrukin ("Fortress of Sargon") as established by Sargon II (721-705 BC), who founded the city between 713 and 707 BC [24]. Its characteristic regular shape appears still preserved in the fields to the east of the modern village of Khorsabad; in fact, the boundaries of the urban area (about 330 ha) can be clearly distinguished, with the remains and traces of the city walls (about $7 \mathrm{~km}$ long) and of the seven monumental gates (Figure $10(1-7)$ ). Of paramount importance in the layout of Dur-Sharrukin is the wish of symmetry, which implies to set two gates in each side of the square, except in the northwest, where one passage is replaced by a monumental bastion built out on both faces of the city wall. The function of this high platform is to support the Royal Palace of Sargon II (Figure $10(\mathrm{~A})$ ), dominating the lower town on the northwest side. At the south-western end of the city, a similar platform, on which is built the so-called Palace F (Figure 10 (B)), protected the entrance through Gate 5, which was connected to the main traffic road to Nineveh.

The regular plan of the city apparently contrasts with some asymmetries which are documented within the Citadel, where are the Palace of Sargon and the Ziggurat, for instance, in the case of Building M, Residence K, and Nabu Temple. Two details of Gambit KH-7 photo taken in 1965 and of a QuickBird-2 image taken in 2003 document the decay of a lot of ancient structures excavated in the XIX-XX centuries, which today are characterised by a very poor state of conservation and damages due to agricultural works [18]. In the Gambit photo are clearly visible the remains 


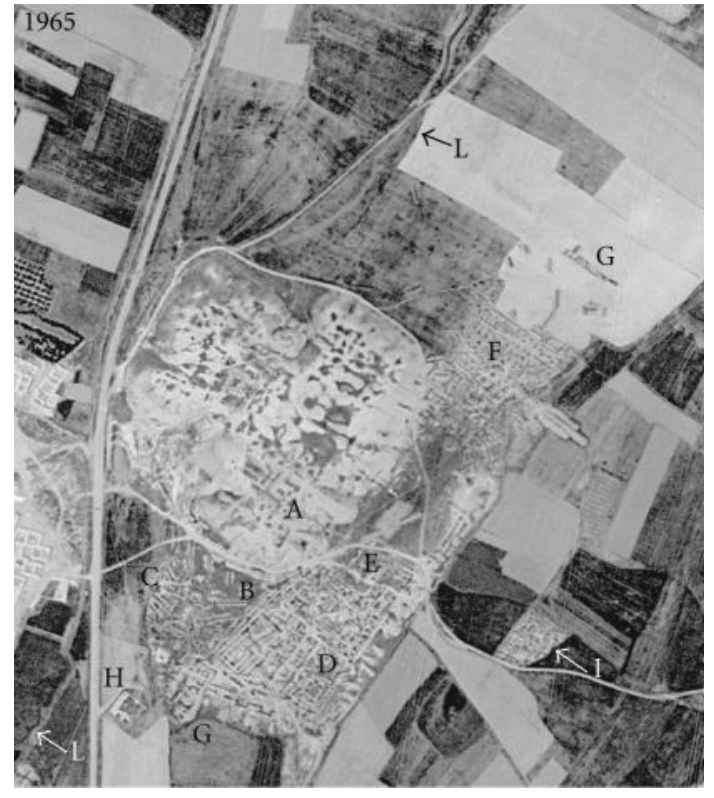

(a)

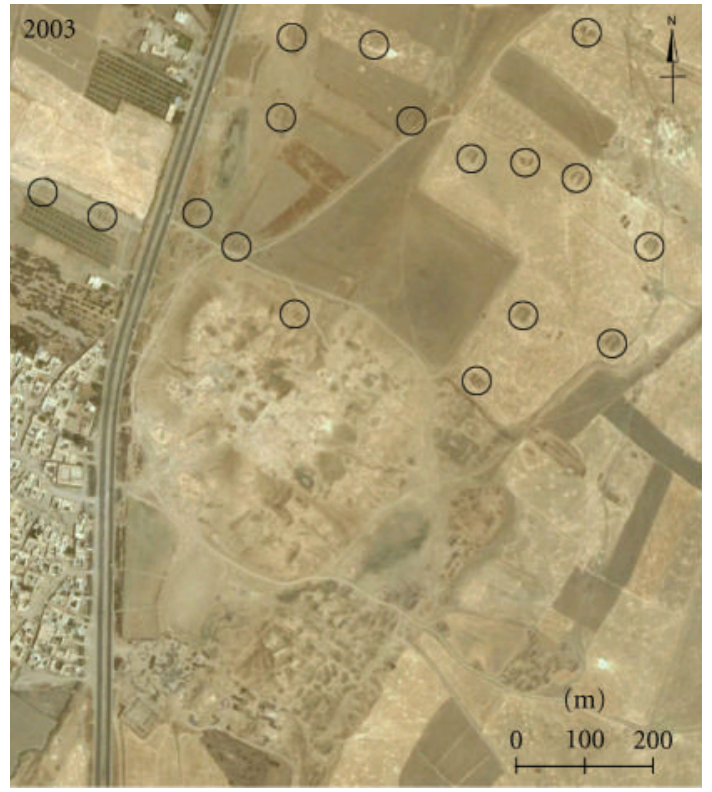

(b)

Figure 11: The Citadel of Dur-Sharrukin in a Gambit KH-7 photo of 1965 and in a pan-sharpened (bands 3-2-1) QuickBird-2 image of 2003: (A) Palace of Sargon; (B) Nabu Temple; (C-F) Residences (M, J, K, and L; G) remains of the walls defending the Citadel; (H) Sibitti Temple; (I) Residence Z; (L) city walls; small circles highlight some military installations.

and the plans of numerous buildings: the Sin, Adad and Shamash temples located on the same platform as the Palace of Sargon (Figure $11(\mathrm{~A})$ ), the Nabu Temple (Figure 11 (B)), and the Residences $\mathrm{M}, \mathrm{J}, \mathrm{K}$, and L (Figure $11(\mathrm{C}-\mathrm{F})$ ), with the rooms arranged around courtyards; of the circuit of walls defending the Citadel, a few remains can be distinguished in the western side, near Gate B, and in the eastern side (Figure $11(\mathrm{G})$ ). Outside the Citadel, the remains of Sibitti Temple and Residence Z (Figure 11 (H-I)), and the traces of the city walls (Figure $11(\mathrm{~L})$ ) can also be seen. In the eastern sector of the Citadel, the image of 2003 also shows some artillery positions of the Iraqi Republican Force; they are arranged in a " $U$ " formation and are even present in the south-eastern corner of Dur-Sharrukin, where a few trenches can be seen. These military installations are visible in the 2002 and 2003 QuickBird-2 images (the last was taken about two months after the end of the Second Gulf War) and are progressively less numerous in the images acquired by the same satellite in 2004 and 2005, in which they appear to have been largely replaced by agricultural activities.

A poor state of conservation characterized also the Palace $\mathrm{F}$ (Figure $12(\mathrm{~A})$ ), intended as private residence for the crown prince Sennacherib and located on a terrace in the southeastern side of the city walls, near Gate 5 (Figure 12 (B)); the remains of the building have been progressively damaged by weathering and agricultural activities. In a Gambit KH-7 photo of 1965, it is possible to distinguish the general plan of the excavated sectors of the palace, containing some rooms and today scarcely preserved; indeed, a Corona $\mathrm{KH}$ photo of 1969 also shows the traces of the palace's internal sector, with a quadrangular general shape, while today this sector is largely used for agriculture.
The Corona KH photo of 1969 provides a general view of the territory of Dur-Sharrukin (Figure 13 (A)) in the fruitful plain of Jebel Bashiqa (ancient Mount Musri) crossed by Khosr River (Figure 13 (B-C)). The area of Dur-Sharrukin, mentioned in the Assyrian inscriptions to have water projects related to its construction, is endowed with a good number of springs that could have been exploited to provide for the city and its surrounding territory $[9,15]$. Furthermore, the Khosr River is not far from Dur-Sharrukin and may have been an important water source. Inscriptions also describe how king Sennacherib, who moved the capital to Nineveh after the death of his father Sargon II in 705 BC (see below), enlarged the openings of several springs at the base of Mount Musri, created reservoirs, and diverted their flow via canals into the Khosr. These works were intended for the new capital water supply; in fact, the plain below Dur-Sharrukin and Tell Billa (ancient Shibaniba: Figure $13(\mathrm{H})$ ) was certainly a major breadbasket region for Nineveh, located to its south-eastern end, at the juncture between the Tigris and the Khosr. The four major springs at the base of the Jebel Bashiqa (from the north: Barima, Fadhiliya, 'Ain Bahr and Bashiqa) are visible in the space photo of 1969 (Figure 13 (D-G)); the springs are recognizable by associated irrigated fields. The two springs above Dur-Sharrukin (at Barima and Fadhiliya) flow through natural channels into the Khosr River, lying in or very close to the ancient urban area.

3.4. Nineveh. Comparing a Gambit KH-7 photo of 1967 (Figure 14) and a WorldView-1 image of 2007 (Figure 15), the considerable expansion of the suburbs of Mosul around the ancient urban area of Nineveh and on its southern sector is evident; for this reason, only the use of old space photos 


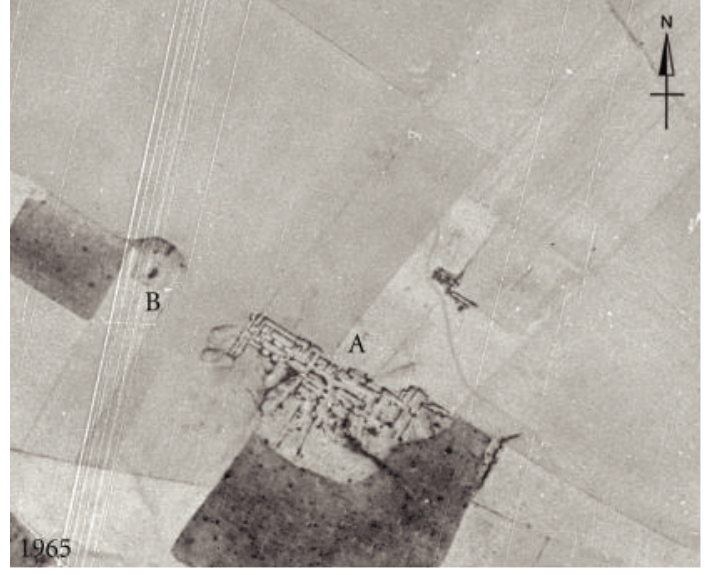

(a)

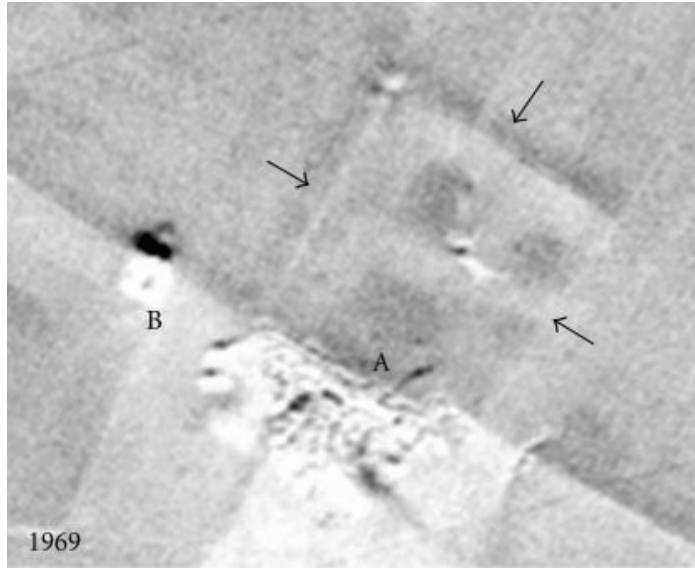

(b)

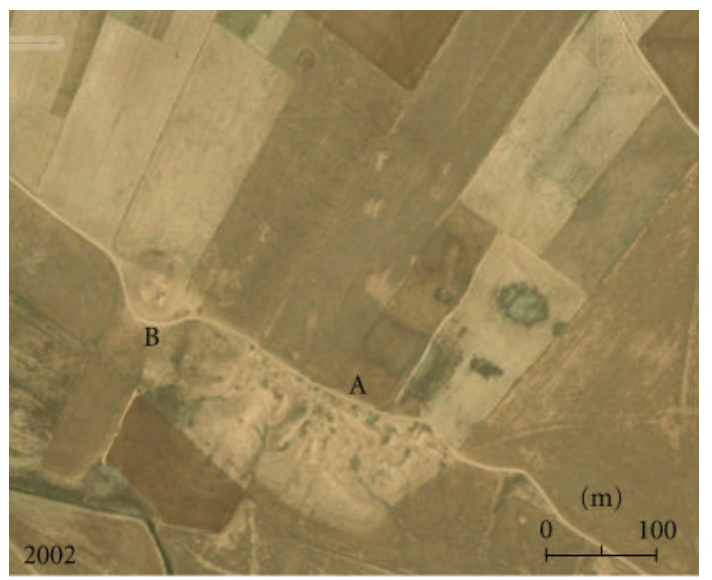

(c)

FIgURE 12: Dur-Sharrukin: the area of Palace F (A) and Gate 5 (B) in a Gambit KH-7 photo (1965), in a Corona KH-4B photo (1969), and in a pan-sharpened (bands 3-2-1) QuickBird-2 image (2002).

provides a fundamental documentation for the reconstruction of the settlement, of the ancient road and canal networks that surrounded it, and of the ancient landscape that characterized the site. The shape and the dimension of the city visible in the images were established by king Sennacherib (704-681 BC), who designed Nineveh, already a royal residence of some Middle Assyrian and Neo-Assyrian kings, as new capital of the Empire. The long city walls (about $12 \mathrm{~km}$ ), which are fitted with fifteen monumental gateways and circumscribe the very large urban area (about 750 ha), can be seen. The wall system consisted of an ashlar stone retaining wall about $6 \mathrm{~m}$ high, surmounted by a mudbrick wall about $10 \mathrm{~m}$ high and $15 \mathrm{~m}$ thick; in the 2007 image it is more evident due to its restoration and reconstruction.

The available space photos of 1960s show very well the ancient landscape in which Nineveh was located, near the eastern bank of the Tigris and its junction with the Khosr River, which flowed through the urban area; the city occupied a strategic position at a Tigris River crossing. Nineveh was built in a flat terrain characterized by two mounds, which rise about $20 \mathrm{~m}$ above the surrounding plain: Kuyunjik (Figure $14(\mathrm{~A})$ ), occupied just during Middle Assyrian period, on which the Temples of Nabu and Ishtar, and the Palaces of Ashurbanipal and Sennacherib were built as well as Nebi Yunus (Figure 14 (B)), which was the ancient arsenal of the city. Around Nineveh, along its northern, eastern and southern sides, traces of ancient moats can be seen as well as the remains of a large canal (Figure $14(\mathrm{~F})$ ): from the Khosr, it flowed about $3.5 \mathrm{~km}$ north-south and then turned to the west reaching the Tigris. It is possible that there was another moat or, better, an ancient arm of the Tigris along the western side of the city; in fact, in this area some traces of paleo-river beds, also running near the city walls, are visible (Figure 14 (C-D)). In the same area, today almost fully urbanized (Figure 15), immediately to the south-west of Kuyunjik mound, the land extends westward (Figure $14(\mathrm{E})$ ), at a bend in the Tigris and at the confluence of this river with the Khosr; in this point, where the bridges between the two sides of the Tigris were always built and, on the western bank of the river, the ancient Mosul was founded, there was an ancient river crossing to which converged important commercial routes.

At the end of the 8th century BC, Sennacherib excavated an elaborate set of canals to bring water from the mountains to the north of Nineveh down onto the plain behind the city, 


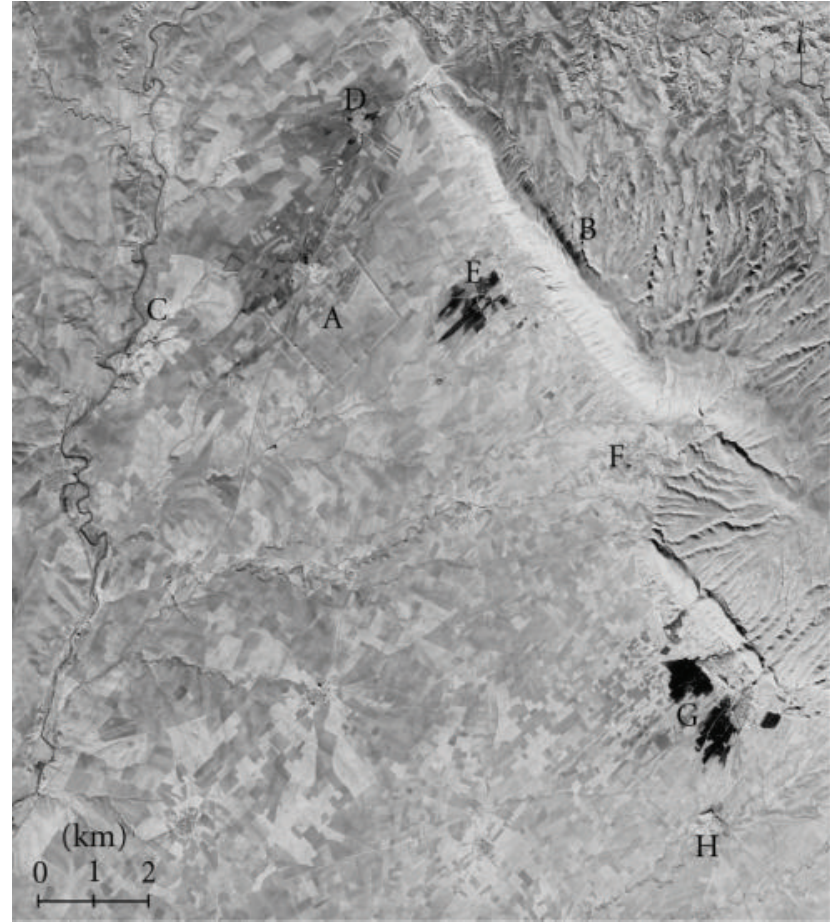

FIgure 13: The territory of Dur-Sharrukin in a Corona $\mathrm{KH}-4 \mathrm{~B}$ photo of 1969: the urban area of the capital city (A), Jebel Bashiqa (B), Khosr River (C), springs at Barima (D), Fadhiliya (E), 'Ain Bahr (F) and Bashiqa (G), and the ancient settlement of Tell Billa $(\mathrm{H})$ are shown.

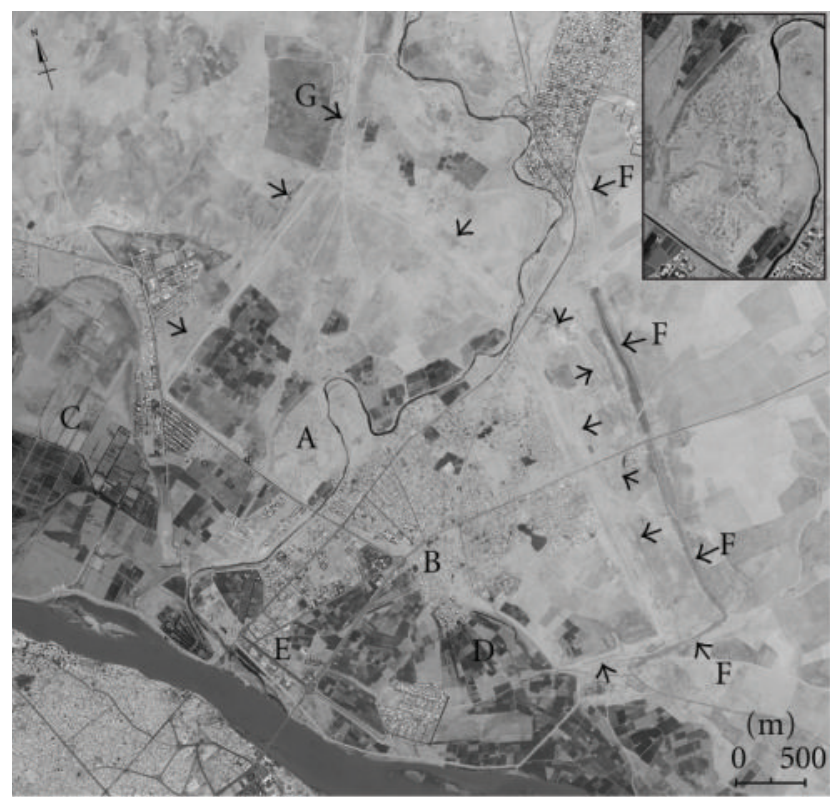

FIGURE 14: Nineveh in a Gambit KH-7 photo of June 9, 1967: (A) Kuyunjik; B, Nebi Yunus; (C-D) area with traces of paleo-river beds; (E) area at the confluence between the Tigris and the Khosr; big arrows show traces and remains of the ancient moats around the city walls, while small arrows point traces and remains of ancient canals (F-G). An enlargement of the image shows the mound of Kuyunjik.

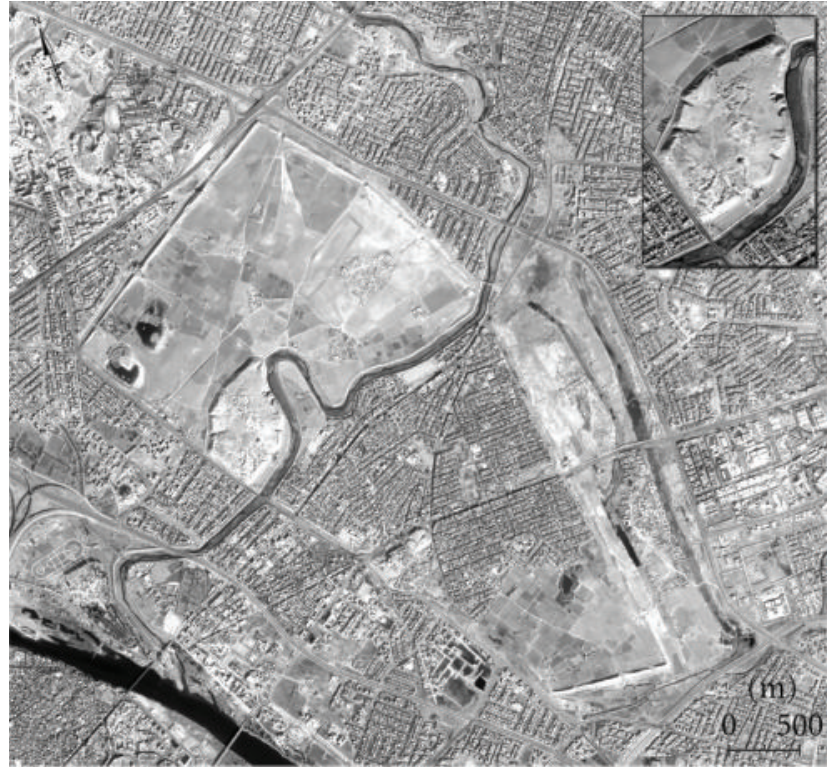

Figure 15: Nineveh in a panchromatic WorldView-1 image of 2007; an enlargement of the image shows the mound of Kuyunjik.

with the aim to intensify agricultural activities $[9-11,14,15]$. The remains and traces of the canal systems planned by the king are visible in the Corona $\mathrm{KH}-4 \mathrm{~B}$ and Gambit $\mathrm{KH}-7$ space photos of the 1960s (Figure 16). These images show a landscape that in the last forty years was much transformed by the expansion of Mosul, new irrigation schemes and diffusion of mechanized agriculture (Figure 17). One of the Sennacherib's waterworks visible in the space photos is the Kisiri canal, built in 705-703 BC, that flowed along or near the present course of the Khosr River. It was connected to the later Khinnis canal ( $688 \mathrm{BC}$ ) to make a larger system that provided more distant waters to Nineveh; this later system cut into the mountains north-east of Nineveh, and water was transported roughly $40 \mathrm{~km}$ from the highlands to the fields north-east and east of the capital. A Corona KH-4B photo of 1967 shows the remains ( $4 \mathrm{~km}$ long) of the Kisiri canal north of Nineveh (Figures $14(\mathrm{G})$ and $16(\mathrm{~A})$ ), near the west bank of the Khosr's present course.

A second ancient canal visible in the satellite images is the Tarbisu, mentioned in one inscription from Sennacherib's reign; this text indicates that it was used for irrigating fruits, grain, and sesame fields in the region of Nineveh. The remains (about $12 \mathrm{~km}$ long) of this canal are visible north of Mosul, lying parallel to the northern bank of the Tigris (Figures 16 (B) and 18 (A)). It originated at the point where the Wadi al-Milh joins the Tigris and ran along the edge of the left river terrace; it transported water to the area of ancient Tarbisu (now the modern village of Sharif Khan, $8 \mathrm{~km}$ north-west of Nineveh), but the remains seem to document its flowing also in the direction of the capital city. So, the Tarbisu canal would have irrigated the fields on the Tigris floodplain upstream from Nineveh. This canal had been probably reused after the Neo-Assyrian period: in fact, it is much more linear than the other canals and its spoil banks are much more defined than those of the other ones. 


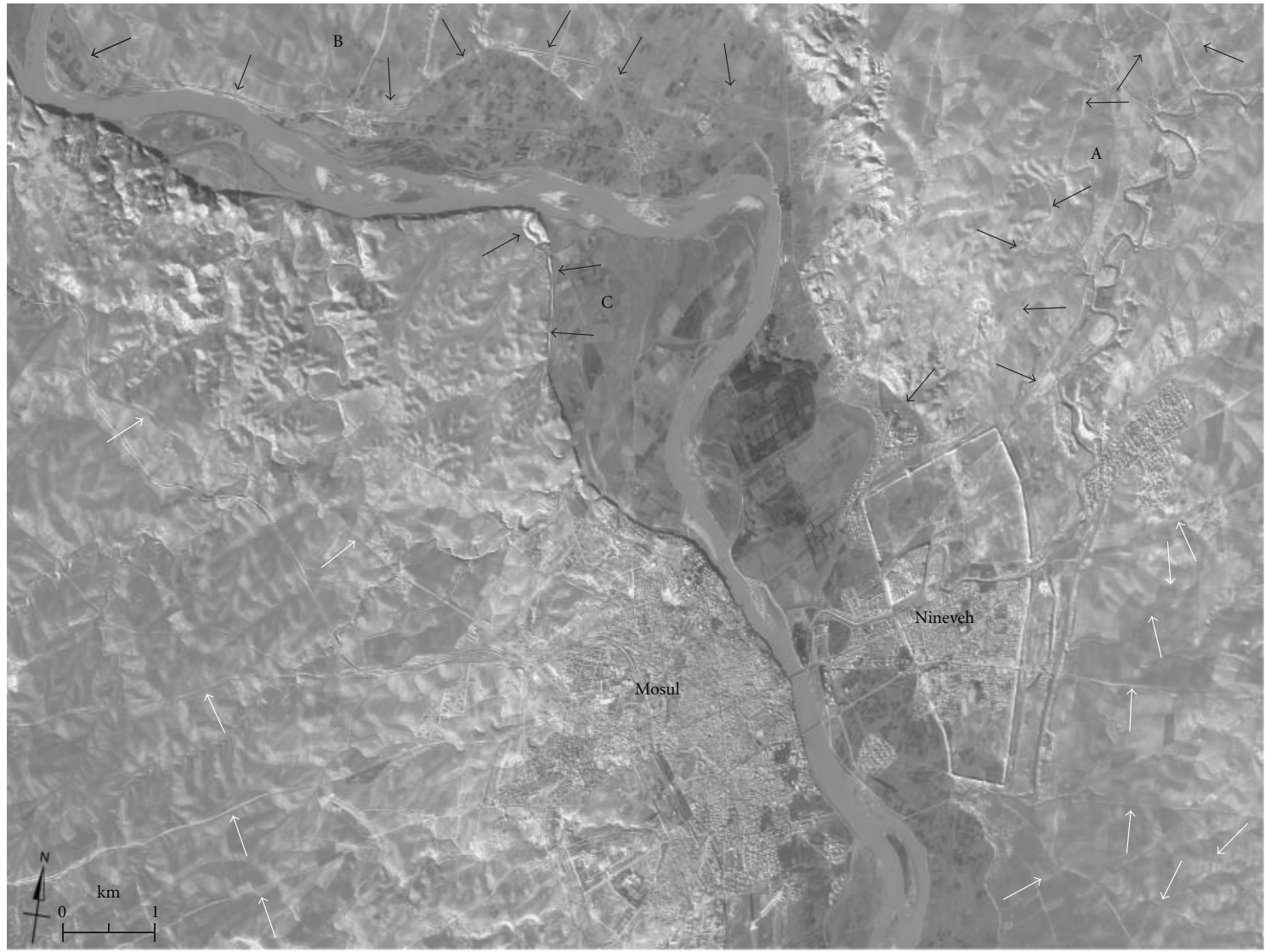

FIgURE 16: The territory of Nineveh in a Corona KH-4B photo of 1967: black arrows show traces and remains of ancient canals ((A) Kisiri canal; (B) Tarbisu canal) and modern waterworks (C), while white arrows point traces and remains of ancient roads.

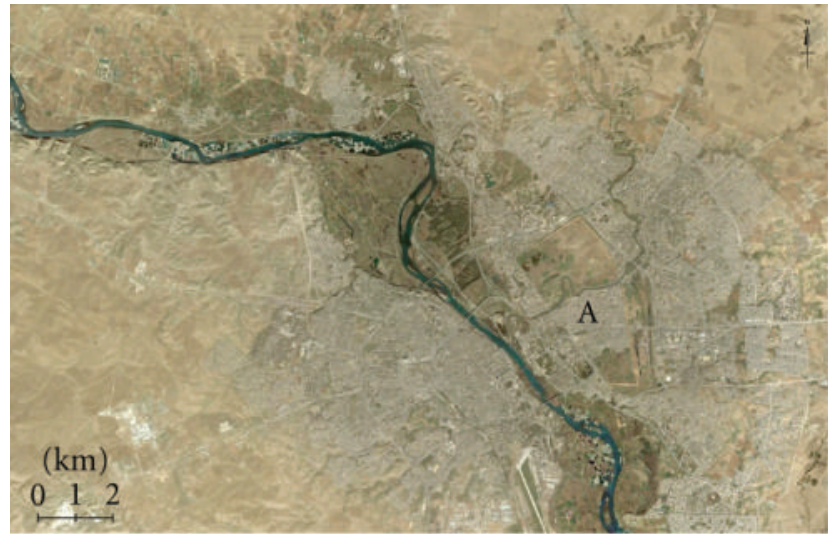

Figure 17: Nineveh (A) and the surrounding territory in a pansharpened (bands 3-2-1) QuickBird-2 image of 2004.

A Gambit KH-7 photo of 1967 clearly shows its remains on the northern bank of the Tigris, in the area of the village of Rashidiya; the image was taken before the building of the Eski Mosul dam, upstream from this area, so the river bed appears larger than today. In a QuickBird-2 image of 2004, the partially destruction of the Tarbisu canal's remains can be seen; it was deleted by agricultural works and expansion of modern villages. In both space photo and satellite image, another canal can be observed in the southern bank of the
Tigris (Figures $16(\mathrm{C})$ and 18 (B)); it appears to be carved or hewn into the bedrock or soil. This feature may have derived its waters from a nearby wadi or the Tigris itself, providing water to the fields just to the west of Mosul; this canal is dated to the 20th century.

Satellite images also provide interesting data concerning the ancient road system around Nineveh $[7,15]$. Many traces of ancient routes (also followed by modern roads) can be seen in the area east and south-east of the city (Figure 16); they seems leading to the Ashur, Shamash, Kar-Mullissi, and Shibaniba Gates, opened along the eastern side of Nineveh's city walls, and connected the new capital to regional cities such as Shibaniba (today Tell Billa) and Kar-Mullissi (today Karmallis), or to the old capital Kalhu. Other traces of ancient roads are also visible to the north and north-east of Nineveh, respectively, in direction of the land between the capital and the mountains and toward Dur-Sharrukin.

Lastly, other linear hollow ways can also be seen in the area west of the Tigris (Figure 16). They connected Nineveh to Neo-Assyrian sites located north-west of Mosul, such as Khirbet Khan, along the ancient route coming from Eski Mosul, still used in Roman times and also documented by the Tabula Peutingeriana [25]. The ancient roads coming from the west also connected Nineveh to the Neo-Assyrian sites located in the area south and south-east Jebel Sheikh Ibrahim, such as Tell Khathir, Tell Khamira, and Tell Herada. 


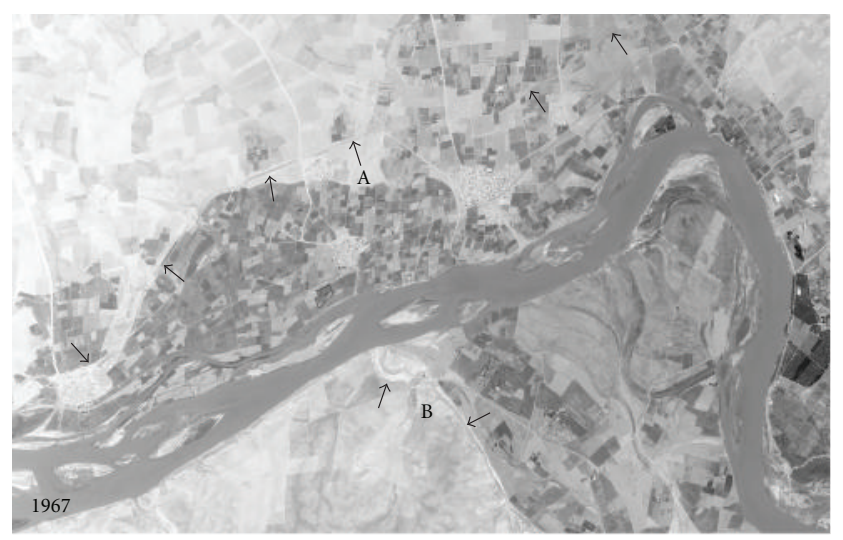

(a)

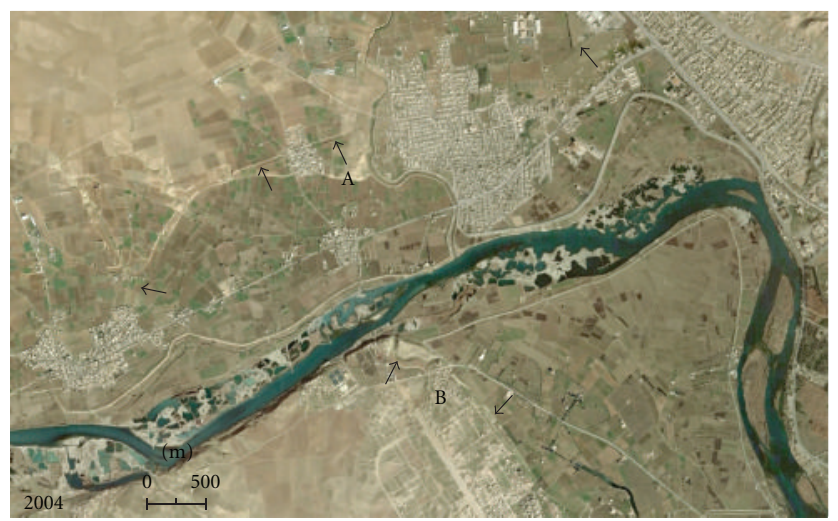

(b)

Figure 18: The remains of the Tarbisu canal (A) in the area of Rashidiya, north-west of Nineveh, visible in a Gambit KH-7 photo of June 9 , 1967, and in a pan-sharpened (bands 3-2-1) QuickBird-2 image of 2004; a canal dated to the 20th century is visible south of the river (B).

\section{Conclusions}

The presented experience shows the importance of the integration of old space photos and modern satellite images, both with very high ground resolution, in the study of archaeological sites and in the reconstruction of historical landscape in ancient Mesopotamia. In fact, the high historical value of the first documentation must be integrated with the high geometric and spectral characteristics of recent images, which have clear benefits for archaeological research. The integration of these two remote-sensing sources is also necessary for monitoring transformations of the landscape and conservation of ancient features. In particular about the Assyrian capital cities, very interesting data emerged during the research using multitemporal satellite images concern the identification of the paleo-river beds of the Tigris, the documentation of ancient urban areas and their layouts, the reconstruction of canals systems and roads networks in the surrounding territories. Remote-sensed data with high geometric resolution allowed the main archaeological elements to be mapped accurately, also with reference to their topographic context. Multitemporality of remote sensed documentation was fundamental in the study of changing in the landscape, while seasonality of data and the use of a multisensor approach were very important in the identification of archaeological features and paleoenvironmental evidence with different characteristics and a good visibility only in some periods of the year.

Lastly, the main causes of damage of the ancient remains during the last half century are weathering (without a preservation policy), mechanized agricultural works, new irrigation schemes, extension of urban areas and the two Gulf Wars (in particular the second). Weathering and damages due to military installations especially concerned Dur-Sharrukin and Nineveh, while land-use modifications have altered the ancient landscape in the surroundings of all Assyrian capital cities and in some cases (Kar-Tukulti-Ninurta, Kalhu and Dur-Sharrukin) also the areas inside them; moreover, the extension of the modern Mosul on the eastern bank of the Tigris have deleted the ancient topography of the territory around Nineveh and partially covered also the area inside the city.

\section{Acknowledgments}

For his constant support during the research activities, I thank Dr. Massimo Cultraro, scientific coordinator of the "Iraq Virtual Museum Project". Special thanks also go to Doctors Laura Castrianni, Giacomo Di Giacomo, Imma Ditaranto, Fabrizio Ghio, and Giuseppe Pellino belonging to the CNR-IBAM team that worked on the study of Iraqi archaeological sites and the processing of satellite images. 


\section{References}

[1] "From space to place," in Proceedings of the 2nd International Conference on Remote Sensing in Archaeology, S. Campana and M. Forte, Eds., CNR, Rome, Italy, December 2006.

[2] "Remote sensing for archaeology and cultural heritage management," in Proceedings of the 1st International Workshop, R. Lasaponara and N. Masini, Eds., Rome, Italy, October 2008.

[3] G. Scardozzi, "Multitemporal satellite high resolution images for the knowledge and the monitoring of the Iraqi archaeological sites: the case of Seleucia on the Tigris," European Journal of applied Remote Sensing, vol. 45, no. 4, pp. 143-160, 2009.

[4] M. Cultraro, F. Gabellone, and G. Scardozzi, "The virtual musealization of archaeological sites: between documentation and communication," in Proceedings of the 14th International Congress on Cultural Heritage and New Technologies, pp. 294 308, Vienna City Hall, Austria, November 2009.

[5] F. Gabellone and G. Scardozzi, "From the object to the territory: image-based technologies and remote sensing for the reconstruction of ancient contexts," Archeologia e Calcolatori, supplement 1, pp. 123-142, 2007.

[6] G. Di Giacomo and G. Scardozzi, "Un webGIS per la conoscenza delle antiche città della Mesopotamia," in Proceedings of the 2nd Congreso Internacional de Arqueología e Informática Gráfica, Patrimonio e Innovación, 2010.

[7] M. R. Altaweel, "The roads of Ashur and Niniveh," Akkadica, vol. 124, pp. 221-228, 2003.

[8] M. Altaweel, "The use of ASTER satellite imagery in archaeological contexts," Archaeological Prospection, vol. 12, no. 3, pp. 151-166, 2005.

[9] J. A. Ur, "Sennacherib's northern Assyrian canals: new insights from satellite imagery and aerial photography," Iraq, vol. 67, pp. 317-345, 2005.

[10] J. A. Ur, "Les imatges per satèllit i l'estructura dels paisatges antics: exemples del Pròxim Orient," Cota Zero, vol. 20, pp. 129-138, 2005.

[11] T. J. Wilkinson, E. Wilkinson, J. A. Ur, and M. R. Altaweel, "Landscape and settlement in the Neo-Assyrian empire," Bulletin of the American Schools of Oriental Research, vol. 340, pp. 23-56, 2005.

[12] B. H. Menze, S. Mühl, and A. G. Sherratt, "Virtual survey on north Mesopotamian tell sites by means of satellite remote sensing," in Broadening Horizons. Multidisciplinary Approaches to the Study of Past Landscapes, pp. 5-29, Cambridge, UK, 2007.

[13] S. Mühl, "Mat Ashur_Land of Ashur. The Plain of Makhmur, Iraq," ArchAtlas, 2007, http://www.archatlas.dept.shef.ac.uk/ workshop/Muehl07.php.

[14] J. A. Ur, "Agricultural and pastoral landscapes in the Near East: case studies using Corona satellite photography," ArchAtlas, 2007, http://www.archatlas.org/workshop/Ur07.php.

[15] M. R. Altaweel, The Imperial Landscape of Ashur: Settlement and Land Use in the Assyrian Heartland, Heidelberger, 2008.

[16] G. A. Beazeley, "Air photography in archaeology," The Geographical Journal, vol. 53, no. 5, pp. 330-335, 1919.

[17] G. A. Beazeley, "Surveys in Mesopotamia during the war," The Geographical Journal, vol. 55, no. 2, pp. 109-127, 1920.

[18] G. Scardozzi, "Old high resolution satellite images for landscape archaeology: case studies from Turkey and Iraq," in Remote Sensing for Environmental Monitoring, GIS Applications, and Geology, vol. 7110 of Proceedings of SPIE, pp. 1-14, 2008.

[19] F. Piccarreta and G. Ceraudo, Manuale di Aerofotografia Archeologica. Metodologia, Tecniche e Applicazioni, Bari, Italy, 2000.
[20] T. J. Wilkinson, "Linear hollows in the Jazira, upper Mesopotamia," Antiquity, vol. 67, no. 256, pp. 548-562, 1993.

[21] T. J. Wilkinson and D. J. Tucker, Settlement Development in the North Jazira, Iraq. A Study of the Archaeological Landscape, Warminster, UK, 1995.

[22] G. Scardozzi, "The contribution of high resolution satellite images to the production of base-maps and cartographies for archaeological research in Turkey and Iraq," in Remote Sensing for Environmental Monitoring, GIS Applications, and Geology, vol. 7478 of Proceedings of SPIE, pp. 1-12, 2009.

[23] F. Gabellone and G. Scardozzi, "Integrated technologies for the reconstructive study of Mesopotamian cultural heritage: the cases of Ur, Uruk and Nimrud," in Proceedings of the International Congress on Cultural Heritage and New Technologies, Vienna, Austria, 2006.

[24] M. Cultraro, F. Gabellone, and G. Scardozzi, "Integrated methodologies and technologies for the reconstructive study of Dur-Sharrukin (Iraq)," in Proceedings of the 21st International Symposium on AntiCIPAting the Future of the Cultural Past (CIPA '07), vol. 1, pp. 253-258, Athens, Greece, 2007.

[25] H. Hauser, "Die mesopotamischen Handelswege nach der Tabula Peutingeriana," in Beiträge zur Kulturgeschichte Vorderasiens. Festschrift für R. M. Boehmer, U. Finkbeiner, R. Dittmann, and H. Hauptmann, Eds., pp. 225-235, 1995. 

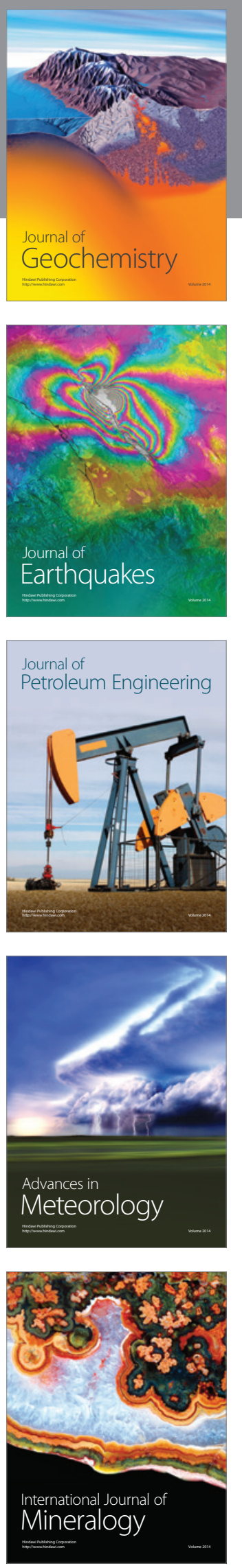
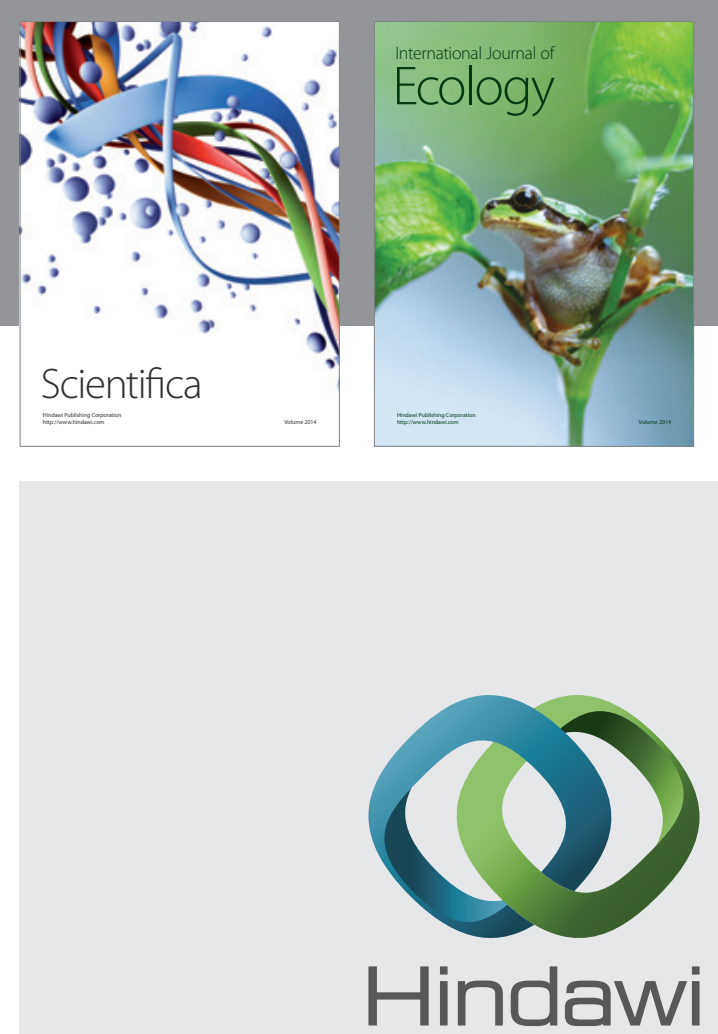

Submit your manuscripts at http://www.hindawi.com
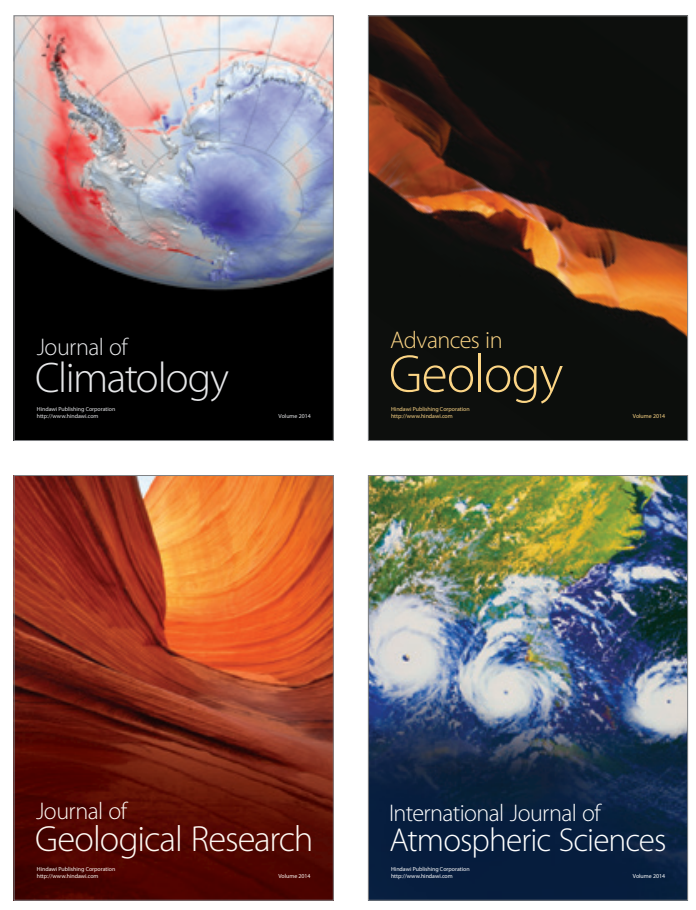
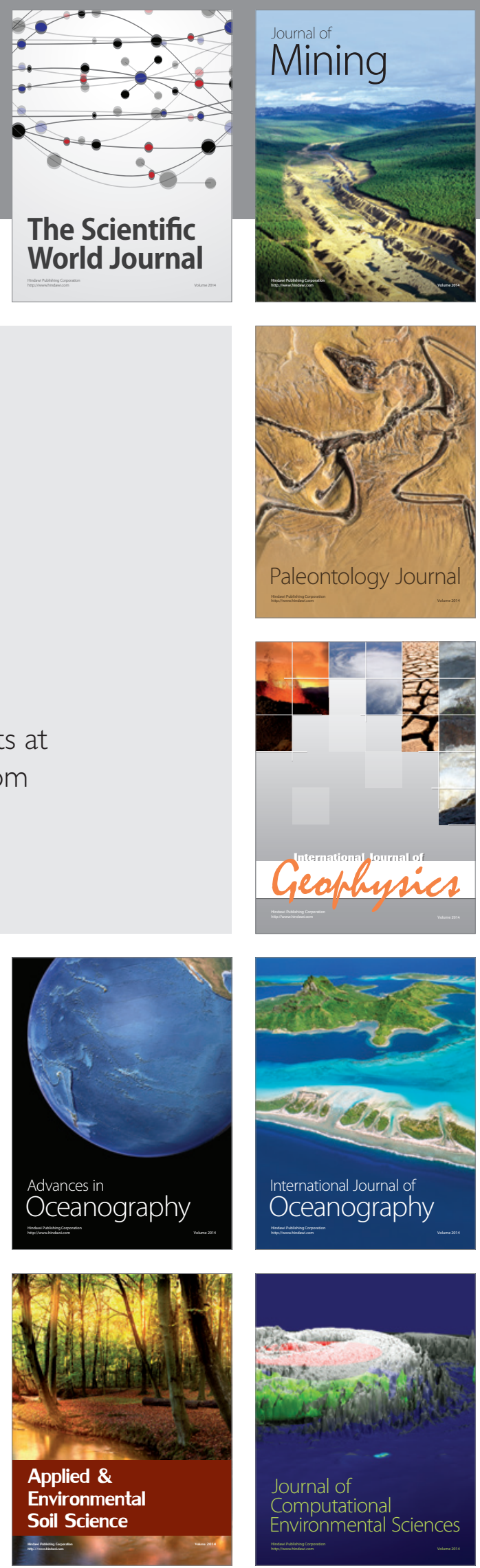